



\section{Effect of partially replacement of soybean meal by processed animal proteins on performance results, intestinal health, litter quality, footpad lesions and bone quality of male broilers}

M. M. van Krimpen, P. Bikker and J. van Harn

This research was conducted by Wageningen Livestock Research, commissioned and funded by the European Fat Processors and Renderers Association (EFPRA), and subsidized by the Ministry of Economic Affairs within the framework of the policy supporting research theme 'TKI-AF-BIO' (project number BO-22.04-007-006). 
Krimpen, M. M. van, P. Bikker, J. van Harn, 2019. Effect of partially replacement of soybean meal by processed animal proteins on performance results, intestinal health, litter quality, footpad lesions and bone quality of male broilers. Wageningen Livestock Research, Report 1184.

\section{Summary UK}

This report presents the methods and results of a study, conducted by Wageningen Livestock Research at the request of EFPRA, in which the effect of partially replacement of soybean meal by two different processed animal proteins (PAPs) of pig origin on performance results, intestinal health, litter quality, footpad lesions and bone quality in broilers chickens from $0-42$ days was evaluated. The two PAPs differ from each other in processing method. From this study it was concluded that it is possible to replace a part of the dietary soybean meal by processed proteins from pig origin, while maintaining performance results, litter quality, footpad health, gait, intestinal health and bone quality.

This report can be downloaded for free at https://doi.org/10.18174/496899 or at www.wur.nl/livestock-research (under Wageningen Livestock Research publications).

\section{(C) 2019 Wageningen Livestock Research}

P.O. Box 338, 6700 AH Wageningen, The Netherlands, T +31 (0)317 4839 53, E info.livestockresearch@wur.nl, www.wur.nl/livestock-research. Wageningen Livestock Research is part of Wageningen University \& Research.

All rights reserved. No part of this publication may be reproduced and/or made public, whether by print, photocopy, microfilm or any other means, without the prior permission of the publisher or author.

Wageningen Livestock Research is NEN-EN-ISO 9001:2015 certified.

All our research commissions are in line with the Terms and Conditions of the Animal Sciences Group. These are filed with the District Court of Zwolle. 


\section{Table of contents}

Foreword $\quad 5$

$\begin{array}{ll}\text { Summary } & 7\end{array}$

1

$\begin{array}{ll}\text { Introduction } & 9\end{array}$

$\begin{array}{lll}1.1 & \text { Background } & 9\end{array}$

$\begin{array}{llr}1.2 & \text { Objective } & 10\end{array}$

2

$\begin{array}{ll}\text { Material and Methods } & 11\end{array}$

2.1 Start date and end date of the experiment 11

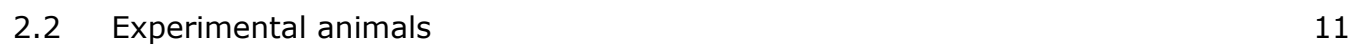

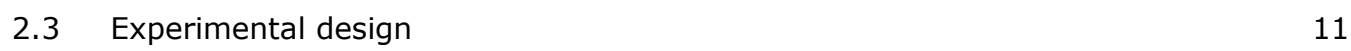

$\begin{array}{lll}2.4 & \text { Experimental facility and housing } & 13\end{array}$

$\begin{array}{lll}2.5 & \text { Experimental diets and feeding } & 13\end{array}$

2.5.1 General 13

$\begin{array}{ll}2.5 .2 \text { Test products } & 14\end{array}$

$\begin{array}{lll}2.6 & \text { Measurements } & 14\end{array}$

$\begin{array}{lll}2.7 & \text { Statistical analysis } & 16\end{array}$

3

$\begin{array}{ll}\text { Results } & 17\end{array}$

$\begin{array}{lll}3.1 & \text { General } & 17\end{array}$

$\begin{array}{lll}3.2 & \text { PAPs and diets } & 17\end{array}$

$\begin{array}{lll}3.3 & \text { Performance results } & 19\end{array}$

$\begin{array}{lll}3.4 & \text { Animal welfare parameters } & 20\end{array}$

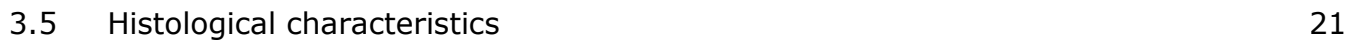

$\begin{array}{lll}3.6 & \text { Blood } & 22\end{array}$

$\begin{array}{ll}3.7 & \text { Bone quality }\end{array}$

$\begin{array}{llr}\text { Conclusions } & 24\end{array}$

$\begin{array}{ll}\text { References } & 25\end{array}$

$\begin{array}{lll}\text { Appendix } 1 & \text { Lay-out experimental room } & 26\end{array}$

$\begin{array}{lll}\text { Appendix } 2 & \text { Realised temperature and humidity } & 27\end{array}$

Appendix 3 Calculated nutrient content of the PAPs 28

$\begin{array}{lll}\text { Appendix } 4 & \text { Experimental diets } & 29\end{array}$

Appendix 5 Processing methods PAPs (EC, 2009) 30

Appendix 6 Scores for friability and wetness of the litter 31

$\begin{array}{lll}\text { Appendix } 7 & \text { Score card footpad lesions broiler chickens } & 32\end{array}$

$\begin{array}{lll}\text { Appendix } 8 & \text { Performance results per feeding phase } & 33\end{array}$

$\begin{array}{lll}\text { Appendix } 9 & \text { Animal welfare } & 35\end{array}$ 



\section{Foreword}

Processed Animal Proteins (PAPs) have long been banned from farm animal diets in the EU. In this period, raw material selection and processes to prepare PAPs have been improved and diversified allowing for a range of products available for inclusion in animal diets. As a consequence, the products and their respective specifications in present feedstuff tables do not cover the composition and quality of presently available PAPs.

EFPRA (European Fat Processors and Renderers Association) represents the European animal byproduct processing sector. Its objective: to continually improve the safety, security and sustainability of European food production by efficiently processing animal by-products into high valuable fats and proteins and other by-products. On request of EFPRA, Wageningen Livestock Research performed a study in which the effect of partially replacement of soybean meal by two different processed animal proteins (PAPs) of pig origin on performance results, intestinal health, litter quality, footpad lesions and bone quality in broiler chickens from $0-42$ days was evaluated. The two PAPs differ in processing method. This report describes the results of this study.

Marinus van Krimpen,

Project leader 


\section{Summary}

Processed Animal Proteins (PAPs) have long been banned from farm animal diets in the EU. In this period, raw material selection and processes to prepare PAPs have been improved and diversified allowing for a range of products available for inclusion in animal diets. On request of EFPRA (European Fat Processors and Renderers Association) Wageningen Livestock Research performed a study in which the effect of partially replacement of soybean meal by two different types of processed animal proteins (PAPs) of pig origin on performance results, intestinal health, litter quality, footpad lesions and bone quality in broiler chickens from $0-42$ days was evaluated.

This study was carried out according to Dutch regulations on animal experiments and animal welfare with 240 Ross 308 male broilers, housed in 24 floor pens bedded with wood shavings, and comprised three treatments: one control diet program and two diets programs in which a part of the soybean meal was replaced by either PAP1 (processing method 1) or PAP2 (processing method 7), processing methods according to (EU) No. 1069/2009, see Appendix 4. Since nutritional values of the PAPs were unknown feeding table values from two meat and bone meals (MBM's) before 2000 were used to formulate the diets (CVB, 2007). The treatments were randomly allotted to the floor pens and each treatment was replicated 8 times, while a replicate was a pen with 10 animals. The broilers received a three phase diet program. Starter, grower and finisher diets were provided from $0-10 d, 10-28 d$ and $28-42 d$, respectively. Feed and water were available for ad libitum intake during the entire experimental period. The temperature was gradually decreased from $34^{\circ} \mathrm{C}$ on day 0 to $20^{\circ} \mathrm{C}$ at 28 days of age and this temperature was remained during the rest of the experimental period. The light was continuously on during the first two days, and thereafter till the end of the experiment a day/night lighting schedule of 18 hours light and 6 hour dark (18L:6D) with a light intensity of 20 lux was provided. Performance results were determined per feeding phase, consecutive feeding phases and over the entire experimental period. At 27 and 41 days of age gait score, litter quality and footpad lesions were determined per pen. At 28 and 42 days of age, 3 birds per pen were dissected. From these animals the left tibia bone was collected to determine the bone quality by measuring the following parameters: 1) tibia morphology (length, thickness, torsion, deformation), 2) tibia stiffness, breaking strength, shear force, 3) bone mineral content and bone density (DEXA). Besides bone quality, the morphological characteristics of the small intestine was assessed by measuring villus height and surface, crypt depth, and number and size of goblet cells per villus. At $42 \mathrm{~d}$ of age also a blood sample of each dissected bird was collected for analysing hormones and metabolites which are involved in the physiology of bone quality ( $\mathrm{Ca}, \mathrm{P}, 1,25$ hydroxy Vit. D3, PTH, Alkaline Phosphatase).

From this study, it was concluded that:

- $\quad$ EPEF did not differ after partial replacement of soybean meal (SBM) by either PAP1 or PAP2, which means that the overall performance results were comparable among all treatments.

- A higher body weight at $\mathrm{d} 10$, and a tendency toward a higher body weight at $\mathrm{d} 42$ was observed after partial replacement of SBM by PAP1.

- Mortality, water consumption, water/feed ratio, and body weight gain did not differ after partial replacement of SBM by either PAP1 or PAP2. Feed intake was increased in birds fed the PAP1 diet program compared to birds fed the control diet program.

- Visual litter quality, severity of footpad lesions and gait score did not differ after partial replacement of SBM by either PAP1 or PAP2.

- $\quad$ Bone quality parameters did not differ after partial replacement of SBM by either PAP1 or PAP2.

- The concentration of Alkaline Phosphatase, Ca, P and vitamin D3 in blood did not differ after partial replacement of SBM by either PAP1 or PAP2. Birds fed the diet with PAP2 had a significant higher Parathyroid Hormone level compared with the control.

- Villus height, crypt depth, number and surface are of goblet cells per villus, goblet cell area, and villus surface area did not differ after partial replacement of SBM by either PAP1 or PAP2.

Compared to the control diet fed birds, at 28 day of age a higher villus/crypt ratio was observed in 
birds fed the PAP2 diets, where at 42 days of age a higher villus/crypt ratio was observed in birds fed the PAP1 diets. 


\section{Introduction}

\section{$1.1 \quad$ Background}

Processed Animal Proteins (PAPs) have long been banned from farm animal diets in the EU. In this period, raw material selection and processes to prepare PAPs have been improved and diversified allowing for a range of products available for inclusion in animal diets.

Processed Animal Protein (PAP) is the collective term for processed products derived from the rendering industry. Some examples of animal protein are: feather or bristle meal, meat and bone meal and blood meal. Animal protein is produced from by-products of animals that have been passed the inspection for human consumption. In general, PAP is a valuable source of energy, protein, minerals and vitamins. Chemical composition, digestibility and nutritional value of different types of PAP varies a lot depending on the origin, bone content and pressure during heat treatment (Hendriks et al., 2004). Knowledge concerning origin, quality and chemical composition of PAP is essential for appropriate diet optimization.

Since the Bovine Spongiform Encephalopathy crises at the end of the last century, regulations on the use of PAP have been tightened. In December 2000, the EU banned the use of all animal proteins from terrestrials in diets for farm animals. So far, no indications have been found that poultry and pigs are susceptible to BSE type diseases. Therefore, PAP derived from poultry and pigs can be used in compound feed without a risk (EFSA, 2011). In 2013 there was a partial lifting of the ban for nonruminant PAP in fish feed. Since 2000, raw material selection and the processes to prepare PAPs have been improved and diversified allowing for a range of products available for inclusion in animal diets. Discussions have been started to reintroduce PAP derived from pork into poultry diets and PAP from poultry into pork diets, but issues regarding the traceability of PAP and the risk for contamination between different PAP sources within feed mills have to be addressed.

Several studies showed that the use of meat and bone meal (MBM) in nutritionally adequate formulated diets did not affect broiler performance (Kim et al. 1993; Drewyor and Waldroup, 2000; Leitgeb et al., 1998 and 2001), although Leitgeb et al. (1998) observed a higher carcass yield in broilers fed diets with MBM. In a study of De Baere and Zoons (2003) vegetable broiler diets adversely affected litter quality, while more hock burns and footpad dermatitis (FPD) lesions have been observed compared to diets with PAP. Eichner et al. (2007) also concluded that broilers fed all-vegetable diets have an increased potential to develop FPD, as well to produce excreta with greater percentage of moisture when compared with those feed diets with poultry by-product.

There are indications that vegetable dietary protein sources can affect intestinal morphology of poultry (Van Leeuwen et al. 2004), but until now limited research has been conducted to measure the effect of PAP on the morphology of the small intestine of broilers. Navidshad et al. (2009) observed that the inclusion of meat meal in broiler diets resulted in a worsened gut morphology as shown by significant lower villus height, crypt depth and crypt depth to villus height ratio in duodenum. Navidshad et al. (2009), however, used 'modified' meat meal a mixture of $60 \%$ meat meal, $15 \%$ wheat bran, $10 \%$ feather meal and $15 \%$ zeolite, where the control diet was a diet with fish meal, which is a highly digestible protein source. The use of fish meal in broiler diets is not common in Western Europe, and the effect of the inclusion of PAPs in a wheat-soybean meal diet on the morphology of the small intestine is currently unknown.

Based on the results from literature, as mentioned above, it was hypothesised that replacing part of the dietary soybean meal by processed proteins from pig origin in broiler diets, will maintaining performance results, litter quality, footpad health, gait, intestinal health and bone quality in broilers. Therefore, on request of EFPRA, Wageningen Livestock Research conducted a study, aiming to study the effects of partially replacement of soybean meal by two different PAPs on the performance results, litter quality, footpad lesions, walking ability (gait), bone quality and morphological characteristics of the small intestine in broilers. 


\subsection{Objective}

The objective of this study was to determine the effect of partially replacement of soybean meal by two different PAPs on the performance results, litter quality, footpad lesions, gait, bone quality and morphological characteristics of the small intestine of male broilers. 


\section{$2 \quad$ Material and Methods}

\subsection{Start date and end date of the experiment}

Date of arrival broilers (day 0 ):

Date of end experiment (day 42):
27 June 2017

8 August 2017

The experiment was conducted at the Research Facility Carus of Wageningen University and Research, Wageningen, The Netherlands.

The broiler chickens used in the study were treated according to Dutch regulations on animal experiments and animal welfare. The experimental protocol (DEC code: 2017.D0014.002) was approved by the ethical committee of Wageningen UR, Wageningen, The Netherlands on 29 June, 2017.

\subsection{Experimental animals}

The experiment was performed with 240 one-day-old male Ross 308 broilers. At the time of arrival at the institute, day-old broilers were weighed and randomly distributed over 24 floor pens (approx. 0.98 $\mathrm{m}^{2} ; 10$ birds/pen) bedded with white wood shavings $\left(2 \mathrm{~kg} / \mathrm{m}^{2}\right)$.

All broilers were vaccinated at 0 days of age (at the hatchery) with Poulvac IB primer against Infectious Bronchitis (IB) and at 15 days with Nobilis Clone 30 against New Castle Disease (NCD). Day-old broilers were sexed at and delivered by Probroed \& Sloot hatchery, Meppel, The Netherlands.

\subsection{Experimental design}

In this experiment with 240 Ross 308 male broilers, housed in floor pens bedded with wood shavings, from 0 - 42 days of age, the performance results, intestinal health, litter quality, footpad lesions and bone quality of male broilers fed a control diet was compared with two diets in which a part of the soybean meal was replaced by either PAP1 (processing Method 1) or PAP2 (processing Method 7). Processing methods are described in Appendix 4 (European Commission, 2002). In total there were three treatments, one control diet program and two programs with the different PAPs (test products). Since nutritional values of the PAPs were unknown, feeding table values from two MBM's before 2000 were used to formulate the diets (CVB, 2011). The treatments were randomly allotted to the floor pens, and each treatment was replicated 8 times, where a replicate was a pen with 10 animals.

A three phase diet program was used: from d0-10 the broilers received starter diets, from d10 - 28 grower diets and from d28-42 finisher diets. All diets were pelletized, starter diets at a 2.5. mm die and grower and finisher diets at a $3.2 \mathrm{~mm}$ die. Feed and water were supplied for ad libitum intake during the entire experimental period $(0-42 d)$. Feed was supplied via a feeding pan (VDL, Valenta, $\varnothing$ $335 \mathrm{~mm}$ ) and the water via one drinking line with three drinking nipples with drip cups (Impex). Figure 2.1 and 2.2 gave an overview of the experimental room and experimental pen, respectively.

Performance results were determined per feeding phase (starter: 0 - 10d; grower: 10 - 28d and finisher: 28 - 42d), over feeding phases (starter + grower: 0 - 28d and grower and finisher: 28 42d) and over the entire experimental period ( 0 - 42d). At 27 and 41 days of age gait score, (visual) litter quality and footpad lesions were determined per pen. At 28 and 42 days of age, randomly 3 birds per pen were dissected. From these animals the left tibia bone was collected to determine the bone quality by measuring the following parameters: 1 ) tibia morphology (length, thickness, torsion, deformation), 2) tibia stiffness, breaking strength, shear force, 3) bone mineral content and bone density (DEXA). Besides bone quality, the morphological characteristics of the small intestine was 
assessed by measuring villus height and surface, crypt depth, and number and size of goblet cells per villus. At $42 \mathrm{~d}$ of age, also a blood sample of each dissected bird was collected for analysing hormones and metabolites which are involved in the physiology of bone quality (Ca, P, 1,25 hydroxy Vitamin D3, PTH, Alkaline Phosphatase).

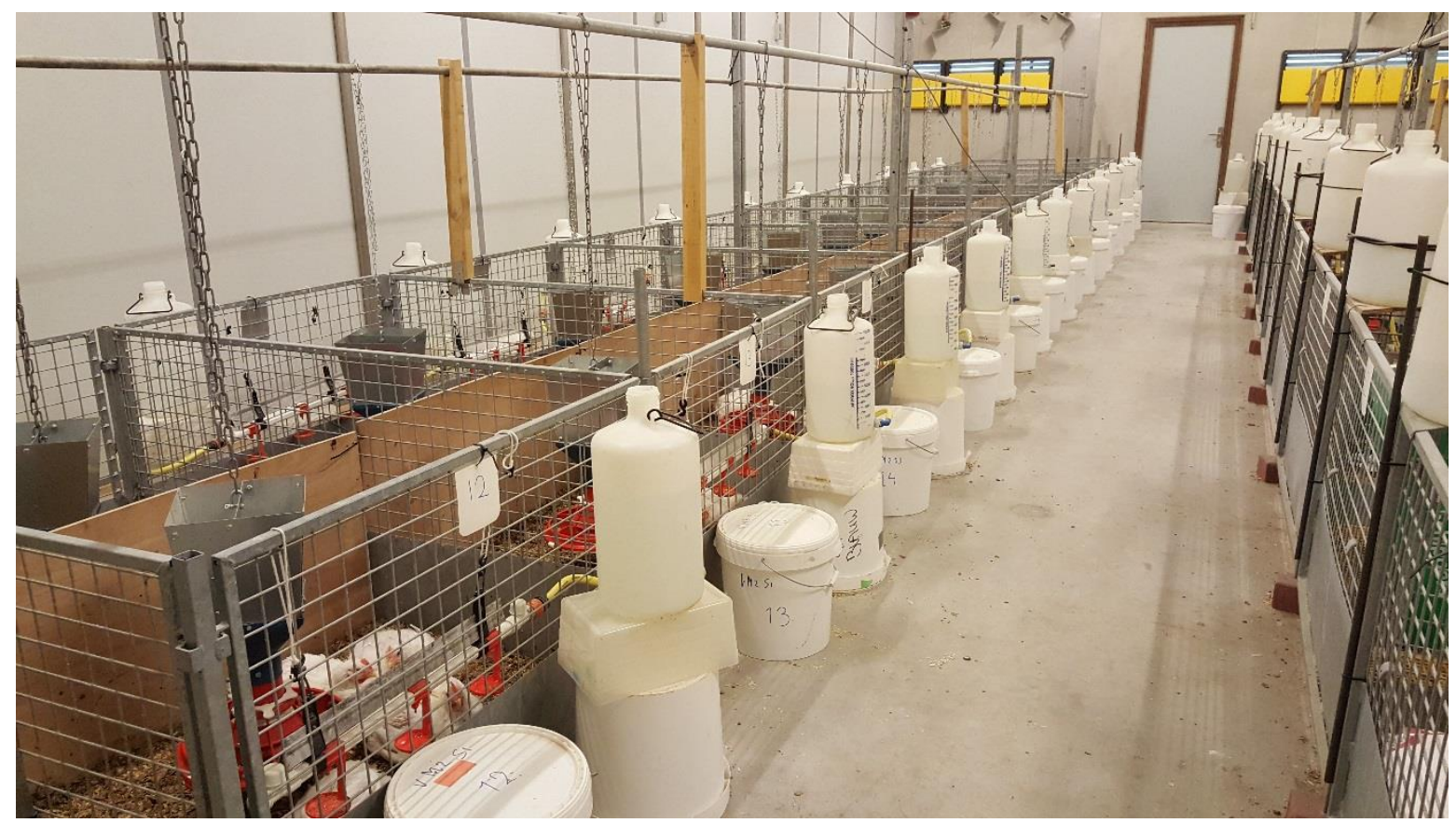

Figure 2.1 Housing of the animals during the pre-experimental period ( 0 - 14 days of age).

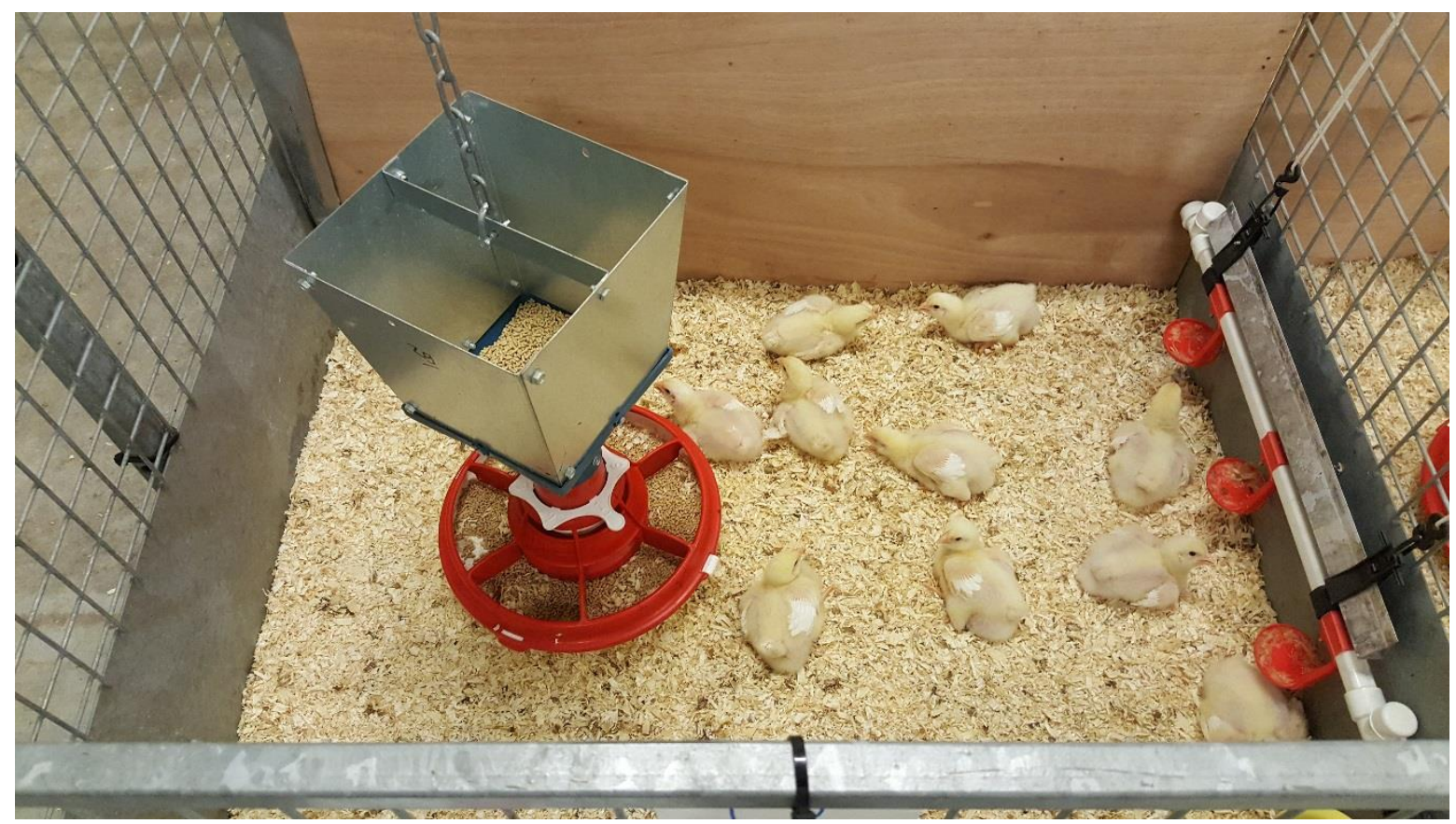

Figure 2.2 Housing of the animals during the experimental period (14 - 23 days of age)

In Table 2.1 an overview of the experimental design is provided, where in Table 2.2 the allocation of the treatments is summarised. Appendix 1 shows the lay-out of the experimental room. 
Table 2.1 Overview of the experimental design.

\begin{tabular}{lr} 
Item & Number \\
Treatments & 3 \\
\hline Broilers per pen & 10 \\
\hline Broilers per treatment & 80 \\
\hline Total number of broilers & 240 \\
\hline Number of blocks & 1 \\
\hline Replicates (pens) per treatment & 8 \\
\hline Total number of pens & 24 \\
\hline
\end{tabular}

Table 2.2 Description of the dietary treatments and allocation of the treatments to the pens.

\begin{tabular}{llll} 
Group & Treatment & Number of animals & Location / pen number \\
1 & Control diet (Control) & $8 * 10=80$ & $3,5,8,12,13,16,20,23$ \\
\hline 2 & Control + PAP1 & $8 * 10=80$ & $2,4,9,10,15,17,21,22$ \\
\hline 3 & Control + PAP2 & $8 * 10=80$ & $1,6,7,11,14,18,19,24$
\end{tabular}

\subsection{Experimental facility and housing}

The experiment was conducted with 240 Ross 308 male broilers in one room at the Research Facility Carus of Wageningen University and Research, Wageningen, The Netherlands. The broilers were housed in 24 floor pens $\left(0.96 \mathrm{~m}^{2}\right)$ bedded with white wood shavings $\left(2 \mathrm{~kg} / \mathrm{m}^{2}\right)$. In each pen 10 birds were housed. Each pen contained a feeding pan (VDL, Valenta, $\varnothing 335 \mathrm{~mm}$ ) and one drinking line with 3 nipple drinkers with drip cups (Impex). During the first three days the feed was also supplied on egg trays.

During the first two days the room was continuously illuminated (24L:0D), thereafter a day/night lighting schedule of 18 hours light and 6 hour dark (18L:6D) was used. The dark period was from 16:00h till 22:00h. Light intensity was 20 lux and ambient temperature was gradually decreased with the age of the bird. Temperature inside the experimental room was increased to $34^{\circ} \mathrm{C}$ one day before arrival of the chicks. From day 1 the temperature was gradually decreased to $20^{\circ} \mathrm{C}$ at day 28 , and this temperature was maintained until the end of the experiment. Appendix 2 gives the setting temperatures and realised temperature and humidity.

Twice a day, in the morning and the afternoon, animals and housing facilities were inspected by animal care takers, thereby checking the general health status, availability of feed and water as well as lighting, temperature and ventilation, and recognizing unexpected events. All incidences were recorded in the Digital Study Log Book.

\subsection{Experimental diets and feeding}

\subsubsection{General}

No actual nutrient digestibility values of the tested PAPs were available when formulating the diets. Therefore, digestible amino acid contents and $A_{M} E_{n}$ values were based on chemical analysis of the PAPs as provided by the EFPRA members and nutrient digestibility coefficients as mentioned in the CVB table (CVB, 2011; PAP from Dutch origin for PAP1 and PAP from foreign origin for PAP2). . The calculated nutrient values of the PAPs are provided in Appendix 3. Diet composition and calculated nutrients of the diets are presented in Appendix 4. A three-phase feeding program was provided. Starter diets were provided from 1-10 days of age, grower diets from 10-28 and finisher diets from 28-42 days of age. The experimental diets were formulated to meet or exceed the CVB requirements (CVB, 2007) for all nutrients. Diets were based on corn, wheat, soybean meal and potato protein and were prepared without the inclusion of any growth promoter or phytase enzyme, but with a NSP enzyme. Starter and grower diets contained a chemical anti-coccidial (Clinacox ${ }^{\circledR}$ ). Within a feeding phase all diets were iso-caloric and had similar calculated digestible essential amino acid profiles, 
calcium and available phosphorus contents. Dietary inclusion level of PAP1 in the starter, grower and finisher diet was 9.0, 8.5 and 9.0\%, respectively. Dietary inclusion level of PAP2 in the starter, grower and finisher diet was 9.0, 7.0 and 6.0\%, respectively. In diet programs 2 and 3, part of the soybean meal was replaced by PAP1 and PAP2, respectively. All diets were pelleted (starter diets at a $2.5 \mathrm{~mm}$ die and grower and finisher diets at a $3.0 \mathrm{~mm}$ die). All diets were produced by Research Diet Services, Wijk bij Duurstede, The Netherlands. Starter diet and experimental diets were delivered in $20 \mathrm{~kg}$ bags. Feed and water were supplied ad libitum during the entire experimental period.

\subsubsection{Test products}

The two processed animal proteins (PAPs), of porcine origin, were delivered by two members of EFPRA. The two PAPs differ in the way they were processed (see Appendix 5):

1. PAP1 - a processing method 1 (pressure sterilisation)

2. PAP2 - a processing method 7.

\subsection{Measurements}

PAPs and diets

Representative samples of both PAPs and all experimental diets were taken during feed production. In the experimental diets the following analysis were conducted: dry matter (DM), ash (ISO 5984), crude protein (CP) (ISO 5983), crude fat (CFat) (ISO 6492), crude fiber (CF) (ISO 6865), starch (ISO 15914), calcium (Ca) (ISO 6869) and phosphorous (P) (ISO6941). All analyses were done in duplicate and carried out by ANU lab of Wageningen University and Research.

\section{- Performance}

Body weight (BW) of birds per pen was determined at 0, 10, 28 and 42 days of age. Feed intake (FI) per pen was determined at 10, 28 and 42 days of age (provided feed minus remaining feed at 10,28 and 42 days of age). Body weight gain (BWG), average daily gain (ADG), feed conversion ratio (FCR), feed intake (FI), average daily feed intake (ADFI) were calculated on a pen basis from these data for the following periods: $0-10 d, 10-28 d, 28-42 d, 10-42 d$ and $0-42 d$. BWG = BW end period - BW start period; $A D G=B W G /$ length period; FCR = (Total FI / (Total BW end period - total BW start period + total BW of dead or culled birds)); FI = FCR $\times$ BWG; ADFI = FI / length period. Potential culling, and mortality, as well as health status were recorded daily (including probable causes of any culling, illness or deaths). EPEF (European Production Efficiency Factor) was calculated per pen over the entire experimental period ( 0 - 42 days). EPEF was calculated as (mean daily body weight gain $(\mathrm{g}) / \mathrm{FCR} * 10) \times(100-\%$ mortality).

a Intestinal health / Dysbacteriosis score

At 28 and 42 days of age, three randomly selected birds per pen (= 24 per treatment) were euthanized by an intravenous injection of T61 (an aqueous solution containing per $\mathrm{ml} 200 \mathrm{mg}$ embutramide, $50 \mathrm{mg}$ mebezoniumiodide, and $5 \mathrm{mg}$ tetracainehydrochloride). Subsequently, the chest cavity and the abdomen were opened and the total intestine was ligated and removed from the bird. The intestinal tract was macroscopic scored for intestinal dysbacteriosis according the system described by Teirlynck et al (2011). Furthermore, a morphological examination of the mid jejunum was performed at these birds. For this, a sample of the mid jejunum was collected, directly after euthanasia. Samples were fixed in $10 \%$ buffered formalin for at least 48 hours. The processing consisted of serial dehydration, clearing and embedding in paraffin. Sections $(2 \mu \mathrm{m})$ were stained with hematoxilin and eosin (Jung Auto Stainer XL). Per sample, up to 10 villi and adjacent crypts where measured. Villus length was measured from the tip of the villus to the villuscrypt junction and was only performed in case of intact lamina propria. Crypt depth was measured from the villus-crypt junction to the basal membrane. Further detection of goblet cells was done using periodic acid Schiff staining as described by Forder et al. (2007).

Bone quality measurements

At 28 and 42 days of age from three animals per pen, the same animals as used for dysbacteriosis score, the left tibia were removed and pooled and coded/labelled per pen ( 24 samples in total) for 
bone quality measurements. Tibia bones were put per pen in plastic bags ( 3 tibias per bag) and stored at $-20{ }^{\circ} \mathrm{C}$ directly after collection. Bone quality was assessed by measuring the following parameters: 1) tibia morphology (length, thickness, torsion, deformation), 2) tibia stiffness, breaking strength, shear force, 3) bone mineral content and bone density (DXA). 1) and 2) were performed at Food and Biobased Research of Wageningen University and Research, whereas 3 ) was performed at Tromp Medical, Castricum, The Netherlands.

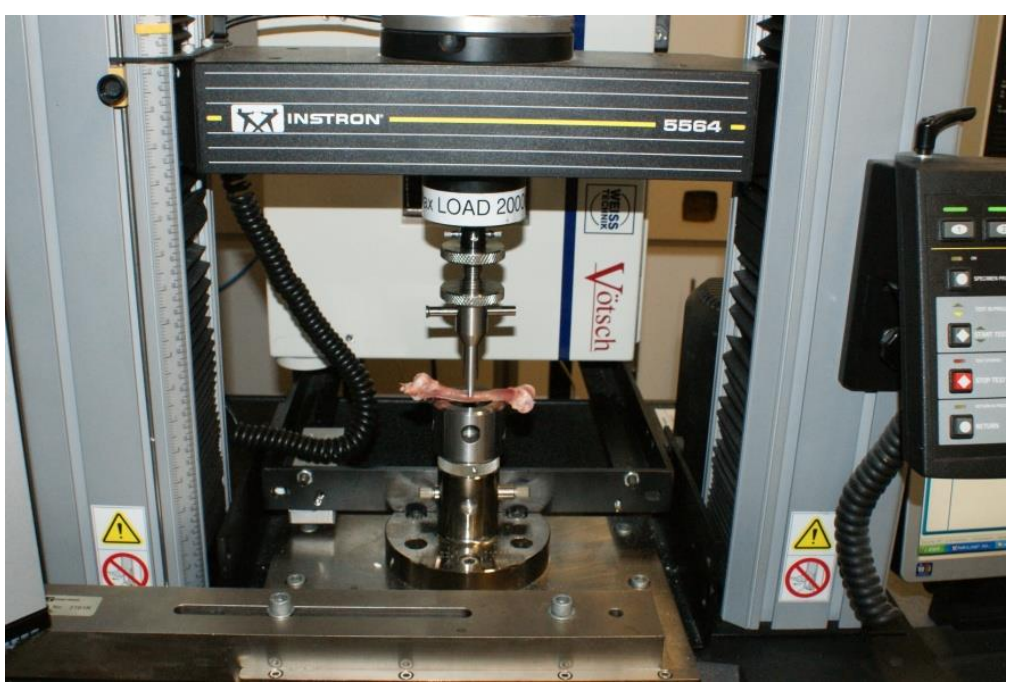

Figure 2.3 Instron materials tester, model 5564, used for measuring the breaking strength of the tibia.

The strength of the tibia was measured with an Instron Materials tester (model 5564) with automated materials test software (Figure 2.3). The breaking point was defined as the point at which the resistance of the bone felled back by $30 \%$, or as the bone was bent by $10 \mathrm{~mm}$. The power used to break the bone was registered 9 times/s by the software of the Instron Materials tester. The total breaking strength was expressed in $\mathrm{Nmm}$. The tibia diameter was measured by the material tester Heidenhain.

\section{Blood sampling}

At 42 days of age blood samples were taken from the three animals per pen to determine the alkaline phosphatase (AP), calcium (Ca), phosphorus (P), Parathyroid Hormone (PTH) and 1,25Dihydroxy-Vitamin D3 contents in the serum. The blood samples were taken from the same animals used for the intestinal health and bone quality measurements just before they were humanely sacrificed by T61. The blood samples were taken from the wing vein. In total 72 (24 pens $\times 3$ animals) blood samples were taken. After collection the blood was centrifuged for approximately 30 minutes. Subsequently, the obtained serum was pooled per pen and divided in 2 aliquots of approximately $1.5 \mathrm{~mL}$ per bird in coded $2.5 \mathrm{~mL}$ cryotubes. One serum sample per pen was sent in for analysis and the other serum sample was stored at $-20^{\circ} \mathrm{C}$ for back-up. Serum samples were analysed for alkaline phosphatase (AP), calcium (Ca), phosphorus (P), Parathyroid Hormone (PTH) and 1,25-Dihydroxy-Vitamin D3 content at Laboklin, Hoensbroek, The Netherlands.

Litter quality assessment

Litter quality was observed at 27 and 41 days of age by an experienced assessor. This person scored friability and wetness of the litter in each pen on a 1 to 10 -point scale. The scores and the description of each score are presented in Appendix 6.

Gootpad quality assessment

Occurrence of footpad lesions and their severity (scale 0, 1, 2) was determined at 27 and 41 days of age by an experienced assessor. All broilers per pen were used for these assessments. Footpad dermatitis was scored per broiler for both feet according to the so-called 'Swedish' classification, i.e. score 0: no lesions or very small discolouration; score 1: discoloration but no deep lesion; 
score 2: deep lesion with ulcers or scabs, bumble foot (Berg, 1998). An overview of scores for footpad lesions is presented in Appendix 7.

The severity of footpad lesions was expressed as footpad score (FPS) per pen. This score is calculated as follows: $100 \% *((0.5 *$ the total number of birds with score 1$)+(2 *$ the total number of birds with score 2)) / the total number of scored birds. The flock FPS ranges from 0 (all birds having no lesions) to 200 (all birds having score 2).

Gait score

The gait score system, as developed by Kestin et al. (1992), has been used to assess the quality of locomotion of the birds. The gait score was determined at 27 and 38 days of age by an experienced assessor. For this, a random sample of 4 birds per pen were assigned a gait score between 0 and 5 (normal, dextrous and agile to incapable of walking). Per pen the average gait score was calculated.

Birds are classified according to these criteria (Kestin et al, 1992):

0 . Normal, dextrous and agile

1. Slight abnormality, but difficult to define

2. Definite and identifiable abnormality

3. Obvious abnormality, affects ability to move

4. Severe abnormality, only takes a few steps

5. Incapable of walking

- Climate

Maximum and minimum temperatures and relative humidity were recorded daily.

\subsection{Statistical analysis}

Growth performance, litter quality, footpad quality, gait score, intestinal health, bone quality and blood parameter results were statistically analysed by ANOVA using GenStat statistical software (Genstat 2015, 18 ${ }^{\text {th }}$ edition, Release 18.1, VSN International Ltd., Hemel Hempstead, UK), using pen as experimental unit and diet as explanatory factor according to the statistical model:

$Y=\mu+\operatorname{diet}_{i}+e_{i}$

$\begin{array}{lll}\frac{\text { Where: }}{\mathrm{Y}} & = & \text { Response parameter } \\ \mu & = & \text { General mean } \\ \text { diet } & = & \text { Effect of diet }(\mathrm{i}=1 \ldots 3) \\ \mathrm{e} & = & \text { Error term }\end{array}$

The $P$-value of the treatment effect and the LSD (least significant differencesof means - $5 \%$ level) were provided per response parameter. Treatment effects with a $P$-value $<0.05$ were considered to be statistically significant. 


\section{Results}

\section{$3.1 \quad$ General}

The experiment was conducted according to the protocol without specific problems or relevant deviations. Day-old broilers arrived healthy and the average body weight of the chickens at arrival was 40.3 grams. Average body weight at 42 days was 833 gram higher ( 3856 vs. 3023 grams), and average feed conversion ratio over the entire experimental period ( 0 - 42 days) was 0.272 points lower ( 1.399 vs. $1.671 \mathrm{~g} / \mathrm{g}$ ) compared to the Ross 308 male broiler performance objectives (Aviagen, 2014) (Figure 3.1). Most likely explanation for these outstanding performance results was the low stocking density: 0 - 14d 10 broilers, $14-28 d 7$ broilers and $28-42 d$ of age 4 broilers per square meter. Ross performance objectives are obtained with field stocking densities ( 18 - 22 broilers per square meter). Overall, mortality of broilers from $0-42$ days was on average $2.6 \%$, which is low for males kept from 0 - 42 days. Mortality was unrelated to the dietary treatment.
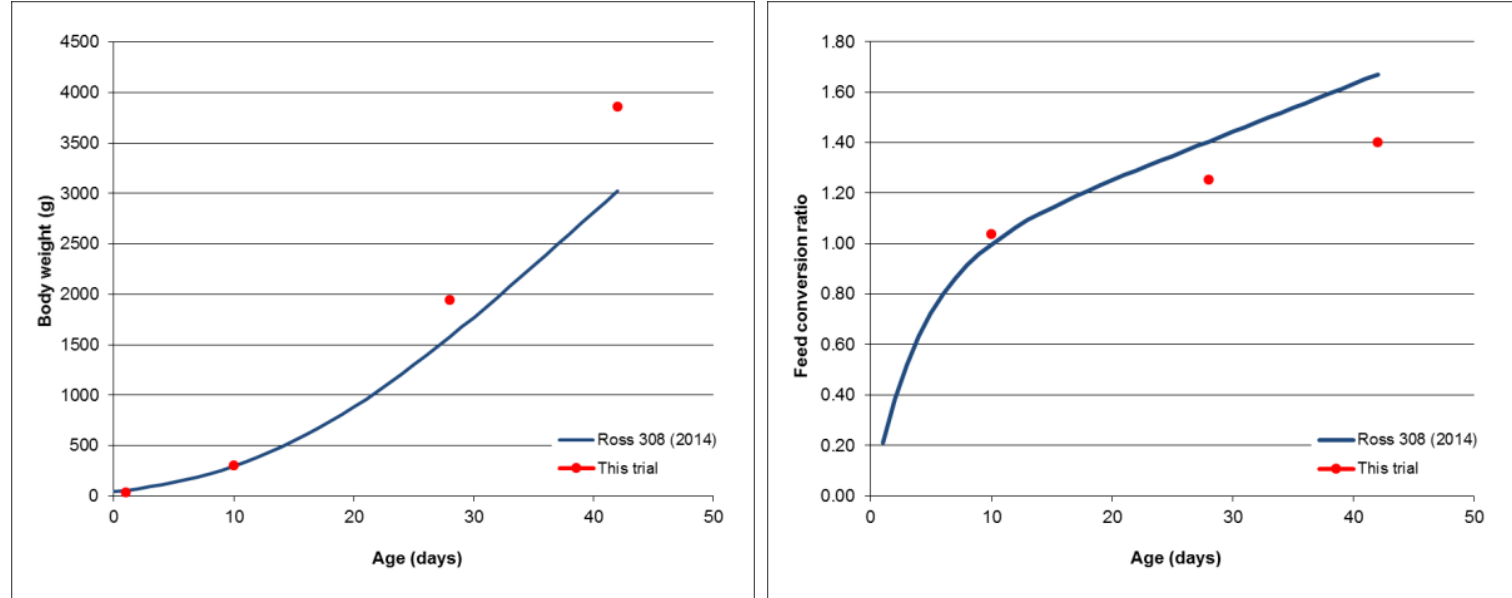

Figure 3.1 Average body weight (left) and feed conversion ratio (right) achieved in this experiment compared with the Ross 308 broiler male performance objectives (Aviagen, 2014).

\subsection{PAPs and diets}

In Table 3.1 the calculated and analysed nutrient composition of the PAPs are given.

Table 3.1 Calculated and analysed nutrient composition of the tested PAPs.

\begin{tabular}{lccrrrr} 
& & \multicolumn{3}{c}{ PAP1 } & & PAP2 \\
& & Calculated & Analysed & Calculated & Analysed \\
\hline Ash & $\mathrm{g} / \mathrm{kg}$ & 98 & 121 & 210 & 233 \\
\hline Dry Matter & $\mathrm{g} / \mathrm{kg}$ & 955 & 946 & 970 & 948 \\
\hline N Dumas & $\mathrm{g} / \mathrm{kg}$ & 99.4 & 97.4 & 99.2 & 96.2 \\
\hline Crude protein $\left(6.25 * \mathrm{~N}_{\text {Dumas }}\right)$ & $\mathrm{g} / \mathrm{kg}$ & 621 & 609 & 620 & 601 \\
\hline Crude fat & $\mathrm{g} / \mathrm{kg}$ & 147 & 144 & 110 & 101 \\
\hline Phosphorus & $\mathrm{g} / \mathrm{kg}$ & 14.7 & 19.3 & 46.0 & 41.9 \\
\hline Calcium & $\mathrm{g} / \mathrm{kg}$ & 18.2 & 28.3 & 84.0 & 78.0
\end{tabular}


The analysed nutrient values indicated that both PAPs contained more ash, phosphorus and calcium, similar fat, and less crude protein than calculated.

In Table 3.2 the calculated and analysed nutrient composition of the starter, grower and finisher diets are given. Also the absolute and relative difference between calculated and analysed contents are given.

The analysed nutrient composition of the starter, the grower and the finisher diets were largely in accordance with the calculated values. The crude fat content was in all feeding phases approx. $6 \mathrm{~g} / \mathrm{kg}$ lower than calculated. In the starter, grower, and finisher phase the crude fibre content was 5, 2, and $2 \mathrm{~g} / \mathrm{kg}$ higher, respectively, than the calculated value. Moreover, the analysed sugar and calcium content was in general slightly higher than the calculated value. The small differences between the calculated and analysed values for crude fat, crude fibre, calcium and sugar can be related to actual differences in nutrient composition of individual ingredients compared to tabulated values on nutrient composition of feed ingredients used in diet formulation (CVB, 2007). 
Table 3.2 The calculated and analysed nutrient composition $(\mathrm{g} / \mathrm{kg})$ of the starter, grower and finisher diets.

\begin{tabular}{|c|c|c|c|c|c|c|c|c|c|c|}
\hline & & \multicolumn{3}{|c|}{ Starter $(0-10 d)$} & \multicolumn{3}{|c|}{ Grower $(10-28 d)$} & \multicolumn{3}{|c|}{ Finisher (28 - 42 d) } \\
\hline & & Control & PAP 1 & PAP 2 & Control & PAP 1 & PAP 2 & Control & PAP 1 & PAP 2 \\
\hline \multicolumn{11}{|l|}{ Analysed } \\
\hline Dry matter & $\mathrm{g}$ & 902 & 906 & 909 & 894 & 900 & 901 & 889 & 896 & 898 \\
\hline Crude protein $(\mathrm{N} \times 6.25)$ & $\mathrm{g}$ & 238 & 236 & 236 & 219 & 229 & 229 & 214 & 221 & 224 \\
\hline Crude fat & $\mathrm{g}$ & 58 & 65 & 64 & 71 & 85 & 76 & 71 & 82 & 78 \\
\hline Crude fibre & $\mathrm{g}$ & 29 & 27 & 24 & 27 & 27 & 28 & 25 & 30 & 25 \\
\hline Crude Ash & $\mathrm{g}$ & 59 & 84 & 95 & 52 & 74 & 70 & 46 & 64 & 65 \\
\hline Starch & $\mathrm{g}$ & 358 & 356 & 364 & 361 & 347 & 356 & 365 & 353 & 357 \\
\hline Sugar & $\mathrm{g}$ & 44 & 34 & 34 & 42 & 33 & 35 & 41 & 36 & 36 \\
\hline Phosphorus & $\mathrm{g}$ & 7.3 & 7.5 & 7.5 & 6.0 & 6.7 & 6.3 & 5.2 & 5.9 & 5.3 \\
\hline Calcium & $\mathrm{g}$ & 9.9 & 10.9 & 10.0 & 8.4 & 9.1 & 7.8 & 6.5 & 7.4 & 6.1 \\
\hline \multicolumn{11}{|l|}{ Calculated } \\
\hline Dry Matter & $\mathrm{g}$ & 882 & 892 & 894 & 883 & 893 & 891 & 882 & 891 & 889 \\
\hline Crude protein & $\mathrm{g}$ & 223 & 225 & 225 & 211 & 220 & 220 & 208 & 215 & 215 \\
\hline Crude Fat & $\mathrm{g}$ & 64 & 69 & 69 & 78 & 89 & 82 & 78 & 90 & 84 \\
\hline Crude fibre & $\mathrm{g}$ & 24 & 20 & 20 & 25 & 25 & 25 & 25 & 25 & 25 \\
\hline Crude ash & $\mathrm{g}$ & 63 & 92 & 99 & 56 & 78 & 72 & 49 & 66 & 65 \\
\hline Starch & $\mathrm{g}$ & 363 & 362 & 362 & 369 & 350 & 361 & 379 & 357 & 367 \\
\hline Sugar & $\mathrm{g}$ & 39 & 28 & 28 & 37 & 28 & 30 & 37 & 31 & 31 \\
\hline Phosphorus & $\mathrm{g}$ & 7.3 & 7.3 & 7.9 & 6.4 & 6.4 & 6.9 & 5.3 & 5.3 & 5.7 \\
\hline Calcium & $\mathrm{g}$ & 9.2 & 9.2 & 9.2 & 7.7 & 7.7 & 7.7 & 6.1 & 6.1 & 6.1 \\
\hline
\end{tabular}

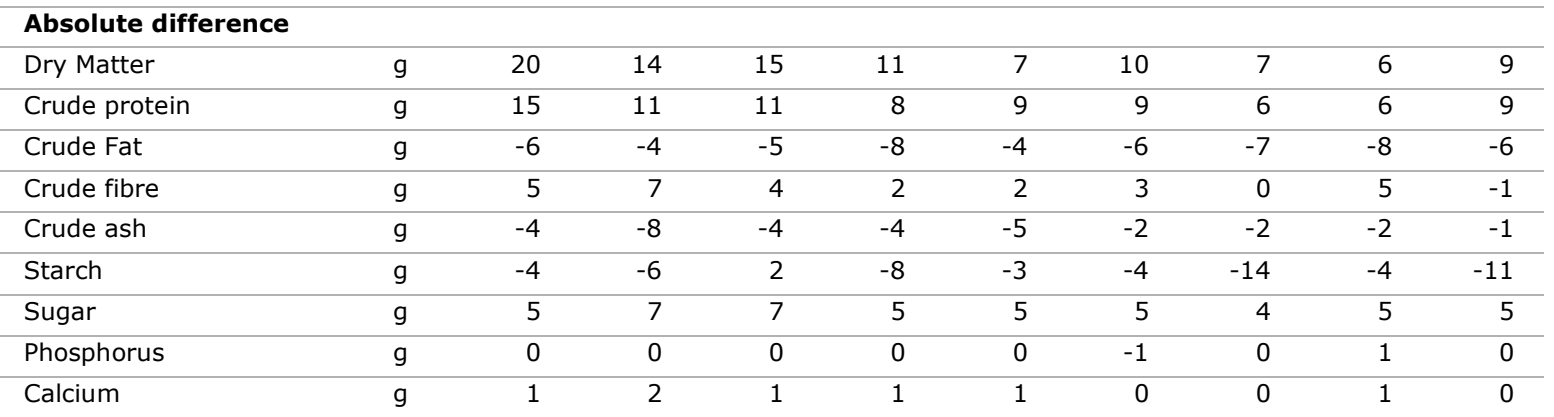

\section{Relative difference}

\begin{tabular}{lrrrrrrrrrr}
\hline Dry Matter & $\%$ & $2 \%$ & $2 \%$ & $2 \%$ & $1 \%$ & $1 \%$ & $1 \%$ & $1 \%$ & $1 \%$ & $1 \%$ \\
\hline Crude protein & $\%$ & $7 \%$ & $5 \%$ & $5 \%$ & $4 \%$ & $4 \%$ & $4 \%$ & $3 \%$ & $3 \%$ & $4 \%$ \\
\hline Crude Fat & $\%$ & $-9 \%$ & $-5 \%$ & $-7 \%$ & $-10 \%$ & $-5 \%$ & $-8 \%$ & $-9 \%$ & $-9 \%$ & $-7 \%$ \\
\hline Crude fibre & $\%$ & $20 \%$ & $34 \%$ & $21 \%$ & $9 \%$ & $10 \%$ & $11 \%$ & $2 \%$ & $21 \%$ & $-2 \%$ \\
\hline Crude ash & $\%$ & $-6 \%$ & $-8 \%$ & $-4 \%$ & $-7 \%$ & $-6 \%$ & $-2 \%$ & $-5 \%$ & $-3 \%$ & $-1 \%$ \\
\hline Starch & $\%$ & $-1 \%$ & $-2 \%$ & $1 \%$ & $-2 \%$ & $-1 \%$ & $-1 \%$ & $-4 \%$ & $-1 \%$ & $-3 \%$ \\
\hline Sugar & $\%$ & $13 \%$ & $24 \%$ & $24 \%$ & $14 \%$ & $20 \%$ & $17 \%$ & $10 \%$ & $14 \%$ & $16 \%$ \\
\hline Phosphorus & $\%$ & $-1 \%$ & $3 \%$ & $-6 \%$ & $-7 \%$ & $5 \%$ & $-8 \%$ & $-2 \%$ & $10 \%$ & $-7 \%$ \\
\hline Calcium & $\%$ & $8 \%$ & $19 \%$ & $9 \%$ & $8 \%$ & $18 \%$ & $1 \%$ & $7 \%$ & $21 \%$ & $0 \%$ \\
\hline
\end{tabular}

\subsection{Performance results}

Table 3.3 provides the effects of the dietary treatments on the performance results over the entire experimental period. In Appendix 8 the performance results per feeding phase and over various feeding phases is given.

Significant effects of the dietary treatments on feed intake (FI) and feed conversion ratio (FCR) over the entire experimental period were observed. Furthermore, compared to broilers fed the control diet program, there was a tendency $(P=0.074)$ towards a higher body weight gain (BWG) of broilers fed the PAP1 diet program. Broilers fed the control diet program had a significant better FCR compared with broilers fed the diet programs in which a part of the soybean meal was replaced by one of the PAPs. However, when the FCR was corrected for weight differences the FCR at a similar weight of 
3850g (FCR 3850g) did not differ between the dietary treatments. Dietary treatment did not affect mortality, water consumption, water/feed ratio and the EPEF.

Over $\mathrm{d}$ 0-10, feed conversion ratio and feed intake were lower for the birds in the control group, compared to groups with the PAPs $(P<0.001)$. On the other hand, BWG was lower in the control group compared to broilers fed PAP1 $(P=0.030)$. Water consumption, water/feed ratio and mortality were not affected by dietary treatment. Over d 10-28 birds fed the control diet program had a significant better FCR than birds who received the diet program with PAP1 $(P=0.006)$. FCR of broilers fed the diet program with PAP2 was intermediate and did not differ from the control. Over d 10-28 no significant differences in body weight gain, water consumption, water/feed ratio and mortality were observed. In the finisher phase ( $d$ 28-42) birds fed the control diet program had a significant better FCR than birds who received the diet program with PAP1 $(P=0.028)$. The FCR of broilers fed the diet program with PAP2 was intermediate and did not differ from the control. No significant differences in feed intake, water consumption, water/feed ratio and body weight gain between experimental treatments were observed in the finisher phase.

Table 3.3 Growth performance results over the entire experimental period ( 0 - 42 days).

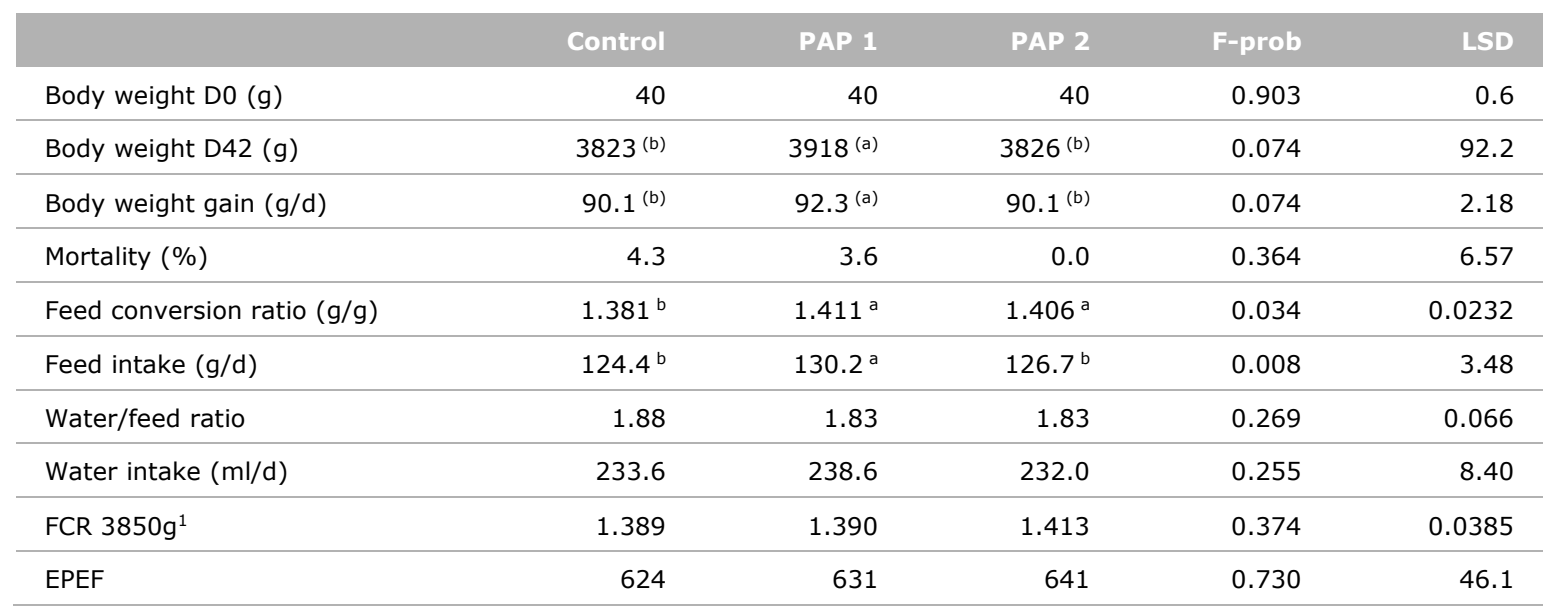

$a, b$ different subscripts in a row mean significant differences $(P<0.05)$

$a, b$ different subscripts in a row in parenthesis indicate near significant differences (tendency) $(0.05 \leq P<0.10)$

${ }^{1}$ FCR was corrected with 0.03 per 100 gram weight difference

\subsection{Animal welfare parameters}

In Table 3.4 the effects of the dietary treatment on litter quality, footpad lesions and gait score is given. Dietary treatment had no significant effect on none of these welfare parameter. At day 27 of age there was a tendency towards dryer litter in the control group. Litter quality (both friability and wetness) and gait decreased with age (Appendix $9, P<.001$ ). In general the litter was friable and relatively dry during the whole experimental period. The (very) low stocking density and favourable outdoor climate were the most likely explanations for the good litter quality. Hardly any footpad lesions were observed. 
Table 3.4 Effect of dietary treatment on visual litter quality, footpad score and gait score at different ages during the experimental period.

\begin{tabular}{|c|c|c|c|c|c|}
\hline & Control & PAP 1 & PAP 2 & F-prob & LSD \\
\hline \multicolumn{6}{|c|}{ Visual litter quality } \\
\hline Friability d $10^{1}$ & 9.0 & 9.0 & 9.0 & & \\
\hline Wetness d $10^{2}$ & 9.0 & 9.0 & 9.0 & & \\
\hline Friability d $27^{1}$ & 8.0 & 7.6 & 7.5 & 0.335 & 0.71 \\
\hline Friability d $41^{1}$ & 6.6 & 6.0 & 6.0 & 0.335 & 0.92 \\
\hline Wetness d $41^{2}$ & 6.8 & 6.6 & 6.6 & 0.813 & 0.70 \\
\hline \multicolumn{6}{|l|}{ Footpad lesions } \\
\hline \multicolumn{6}{|l|}{ Gait } \\
\hline Gait score ${ }^{4}$ d 27 & 2.5 & 2.3 & 2.5 & 0.500 & 0.30 \\
\hline Gait score ${ }^{4}$ d 38 & 2.9 & 3.0 & 2.9 & 0.339 & 0.18 \\
\hline
\end{tabular}

$\mathrm{a}, \mathrm{b}$ different subscripts in a row in parenthesis indicate near significant differences (tendency) $(0.05 \leq \mathrm{P}<0.10)$

1 - 10: 1 completely caked - 10 completely friable;

$21-10$ : 1 very wet - 10 dry;

3 FPS $=$ Footpad score; FPS $=((\% S c 1 * 0.5)+(\% S c 2 * 2))($ Berg, 1998$) ;$

4 score 1 - 5: normal, dextrous and agile to incapable of walking (Kestin et al, 1992).

\subsection{Histological characteristics}

Tables 3.5 and 3.6 present the results of the effects of dietary treatments on villus length, crypt depth, villus/crypt ratio, number of goblet cells, goblet cell area, villus surface area and the total goblet cell area as percentage of villus surface area in the mid jejunum on 28 and 42 days of age, respectively. The measured histological parameters did not differ among the dietary treatment, except the villus/crypt ratio, but the effect was not constant over time. At 28 days, broilers fed the PAP2 diet program had a significant higher $\mathrm{V} / \mathrm{C}$ ratio than broilers fed the control diet program $(P=0.014)$, while the $\mathrm{V} / \mathrm{C}$ ratio of broilers fed the diet program PAP1 did not differ from those who received the control diet program. At 42 days of age broilers fed the diet program with PAP1 had a significant higher V/Cratio compared with the broilers fed the control diet program $(P=0.014)$.

At 28 and 42 days, a general necropsy was performed and special attention was drawn to changes in the peritoneal cavity, lungs, heart, liver, spleen, kidney and intestinal tract. In summary, no gross pathology changes related to the experimental treatments were observed.

Table 3.5 Histological characteristics of the mid jejunum of broilers at 28 days of age.

\begin{tabular}{|c|c|c|c|c|c|c|}
\hline & & Control & PAP 1 & PAP 2 & F-prob & LSD \\
\hline Crypt depth (C) & $\mu \mathrm{m}$ & 161 & 156 & 143 & 0.106 & 17 \\
\hline $\mathrm{V} / \mathrm{C}$ ratio & $\mu \mathrm{m}$ & $6.31^{b}$ & $6.77^{a b}$ & $7.22^{a}$ & 0.014 & 0.59 \\
\hline Number of goblet cells per villus & $\mathrm{n}$ & 202 & 229 & 232 & 0.239 & 39 \\
\hline Goblet cell area & $\mu \mathrm{m}$ & 19.4 & 20.1 & 21.1 & 0.206 & 1.9 \\
\hline Villus surface area & $\mu \mathrm{m}^{2}$ & 208447 & 221183 & 211567 & 0.730 & 34510 \\
\hline Total goblet cell area as $\%$ villus surface & & 1.94 & 2.12 & 2.37 & 0.124 & 0.418 \\
\hline
\end{tabular}


Table 3.6 Histological characteristics of the mid jejunum of broilers at 42 days of age.

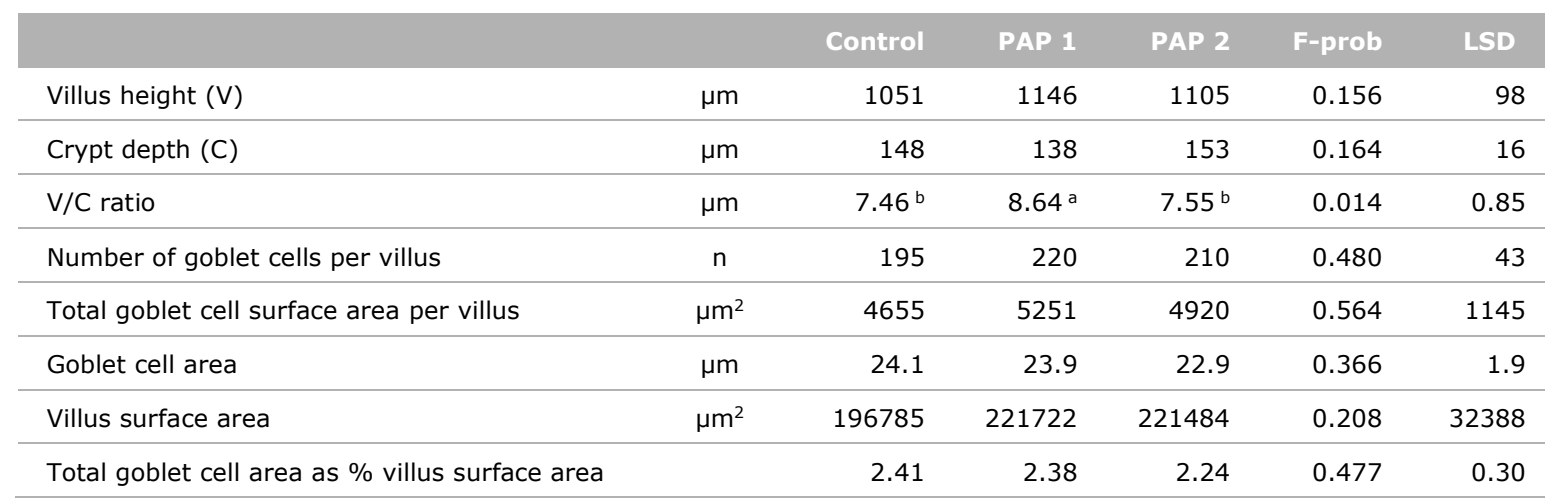

\subsection{Blood}

Table 3.7 shows the concentrations of alkaline phosphatase (AP), calcium (Ca), phosphorus ( $P$ ), parathyroid hormone (PTH) and 1,25-dihydroxy-vitamin D3 (vitD3) in blood of the broilers at d 42 of the study. There was no influence of the dietary treatments on the AP, Ca, P and vitD3 concentration in blood. However, the PTH concentration in the blood of broilers fed the PAP2 diet program was higher compared to birds fed the control diet program $(P=0.009)$.

Table 3.7 Blood parameters at 42 days of age.

\begin{tabular}{|c|c|c|c|c|c|c|}
\hline & & Control & PAP 1 & PAP 2 & F-prob & LSD \\
\hline Alkaline phosphatase (AP) & $\mathrm{U} / \mathrm{I}$ & 2141 & 2294 & 2033 & 0.526 & 473 \\
\hline Calcium & $\mathrm{mmol} / \mathrm{l}$ & 2.75 & 2.76 & 2.70 & 0.606 & 0.14 \\
\hline Phosphorus & $\mathrm{mmol} / \mathrm{l}$ & 2.30 & 2.36 & 2.45 & 0.184 & 0.16 \\
\hline Parathyroid Hormone (PTH) & $\mathrm{pg} / \mathrm{l}$ & $116^{b}$ & $83^{b}$ & $244^{a}$ & 0.009 & 101 \\
\hline 1,25-Dihydroxy-Vitamin D3 & $\mathrm{pg} / \mathrm{l}$ & 230 & 241 & 357 & 0.231 & 165 \\
\hline
\end{tabular}

\subsection{Bone quality}

Tables 3.8 and 3.9 presents the effects of the dietary treatments on the tibia breaking strength and the results of the DXA scan of the tibias collected at 28 and 42 days of age, respectively. At d28 of age the compressive load to break the tibia bone of broilers fed the PAP1 and PAP2 diet program tended to be higher and lower, respectively, compared with birds fed the control diet program (Table 3.8).

Table 3.8 Effect of the dietary treatment on the tibia breaking strength characteristics of male broilers at 28 and 42 days of age.

\begin{tabular}{|c|c|c|c|c|c|c|}
\hline & & Control & PAP 1 & PAP 2 & F-prob & LSD \\
\hline \multicolumn{7}{|l|}{ Day 28} \\
\hline Maximum compressive load & $\mathrm{N}$ & $381^{a b}$ & $410^{a}$ & $348^{\mathrm{b}}$ & 0.031 & 44.6 \\
\hline Energy to fracture & $\mathrm{Nmm}$ & 359 & 390 & 362 & 0.728 & 89.2 \\
\hline Stiffness & $\mathrm{N}$ & 347 & 376 & 326 & 0.127 & 49.1 \\
\hline Thickness & $\mathrm{Mm}$ & $7.3^{(b)}$ & $7.6^{(a)}$ & $7.3^{(b)}$ & 0.060 & 0.27 \\
\hline \multicolumn{7}{|l|}{ Day 42} \\
\hline Maximum compressive load & $\mathrm{N}$ & 366 & 383 & 384 & 0.773 & 59.0 \\
\hline Energy to fracture & $\mathrm{Nmm}$ & 364 & 397 & 406 & 0.713 & 111.5 \\
\hline Stiffness & $\mathrm{N}$ & 415 & 427 & 423 & 0.930 & 62.8 \\
\hline Thickness & $\mathrm{Mm}$ & 9.3 & 9.5 & 9.4 & 0.602 & 0.51 \\
\hline
\end{tabular}


At d27 birds fed the PAP1 diet program tended to have thicker tibia bones compared to birds fed one of the other two diet programs $(P=0.06)$.

At 42 days the dietary treatment did not affected the tibia breaking strength characteristics.

The measured DXA parameters did not differ among the dietary treatments, except the bone mass density (BMD), but the treatment effect was not consistent (Table 3.9). At 28 days of age birds fed the control diet program had a significant higher BMD compared to birds fed the PAP2 diet program $(P=0.040)$. On 42 days, the BMD of birds fed the PAP2 diet program was higher than those who received the control diet program.

Table 3.9 Effect of the dietary treatment on the results of the DXA scan of tibia bones of male broilers collected at day 28 and 42 of age.

\begin{tabular}{|c|c|c|c|c|c|c|}
\hline & & Control & PAP 1 & PAP 2 & F-prob & LSD \\
\hline \multicolumn{7}{|l|}{ Day 28} \\
\hline Area & $\mathrm{cm}^{2}$ & 21.46 & 21.68 & 20.57 & 0.422 & 1.81 \\
\hline Bone Mass Content (BMC) & G & 4.27 & 4.17 & 3.72 & 0.125 & 0.57 \\
\hline Bone Mass density (BMD) & $\mathrm{g} / \mathrm{cm}^{2}$ & $0.198^{a}$ & $0.192^{a b}$ & $0.180^{b}$ & 0.040 & 0.014 \\
\hline Fat Mass & G & 2.9 & 3.2 & 3.1 & 0.894 & 1.5 \\
\hline Lean Bone Mass Content & G & 48.4 & 48.8 & 46.6 & 0.279 & 2.9 \\
\hline Total Mass & G & 51.4 & 52.0 & 49.8 & 0.400 & 3.4 \\
\hline Fat & $\%$ & 5.6 & 6.1 & 6.2 & 0.899 & 2.8 \\
\hline \multicolumn{7}{|l|}{ Day 42} \\
\hline Area & $\mathrm{cm}^{2}$ & 36.61 & 36.70 & 38.02 & 0.573 & 3.1 \\
\hline Bone Mass Content (BMC) & G & 7.64 & 8.27 & 8.72 & 0.155 & 1.1 \\
\hline Bone Mass density (BMD) & $\mathrm{g} / \mathrm{cm}^{2}$ & $0.208^{b}$ & $0.225^{a b}$ & $0.228^{a}$ & 0.048 & 0.017 \\
\hline Fat Mass & G & 7.5 & 7.4 & 9.1 & 0.332 & 2.6 \\
\hline Lean Bone Mass Content & G & 89.1 & 88.4 & 89.8 & 0.922 & 7.3 \\
\hline Total Mass & G & 96.6 & 95.8 & 98.9 & 0.640 & 7.07 \\
\hline Fat & $\%$ & 7.9 & 7.7 & 9.1 & 0.479 & 2.7 \\
\hline
\end{tabular}




\section{Conclusions}

From this study, in which the effect of partially replacement of soybean meal by two PAPs who differed in the way they were processed on the performance results, litter quality, footpad lesions, gait, bone quality and morphological characteristics of the small intestine of male broilers can be concluded that:

- EPEF did not differ after partial replacement of SBM by either PAP1 or PAP2, which means that the overall performance results were comparable among all treatments.

- A higher body weight at $\mathrm{d} 10$, and a tendency toward a higher body weight at d42 was observed after partial replacement of SBM by PAP1.

- Mortality, water consumption, water/feed ratio, and body weight gain did not differ after partial replacement of SBM by either PAP1 or PAP2. Feed intake was increased in birds fed the PAP1 diet program compared to birds fed the control diet program.

- Visual litter quality, severity of footpad lesions and gait score did not differ after partial replacement of SBM by either PAP1 or PAP2.

- $\quad$ Bone quality parameters did not differ after partial replacement of SBM by either PAP1 or PAP2.

- The concentration of Alkaline Phosphatase, Ca, P and vitamin D3 in blood did not differ after partial replacement of SBM by either PAP1 or PAP2. Birds fed the diet with PAP2 had a significant higher Parathyroid Hormone level compared with the control.

- Villus height, crypt depth, number and surface are of goblet cells per villus, goblet cell area, and villus surface area did not differ after partial replacement of SBM by either PAP1 or PAP2.

Compared to the control diet fed birds, at 28 day of age a higher villus/crypt ratio was observed in birds fed the PAP2 diets, where at 42 days of age a higher villus/crypt ratio was observed in birds fed the PAP1 diets.

In general, it can be concluded that it is possible to replace part of the dietary soybean meal by one of the tested processed animal proteins, while maintaining performance results, litter quality, footpad lesions, gait, bone quality or intestinal health of male broilers. Both PAPs can be considered as suitable replacers of SBM in broiler diets. 


\section{References}

Aviagen, 2014. Ross 308 Performance objectives 2014.

Baere de, Kris en Johan Zoons, 2003. Strooiselkwaliteit bij vleeskuikens: een belangrijk aandachtspunt. Pluimvee nr. 36

Berg, C., 1998. Footpad dermatitis in broilers and turkeys. Doctoral diss. Dept. of Animal Environment and Health, SLU. Acta Universitatis Agriculturae Sueciae, Sweden.

CVB, 2011. Feeding Table (Veevoedertabel). Centraal Veevoederbureau, Lelystad, The Netherlands.

Drewyor, M. A., and P. W. Waldroup, 2000. Utilization of high levels of meat and bone meal in broiler diets. J. Appl. Poult. Res. 9: 131-141.

Eichner, G., S.L. Vieira, C.A. Torres, J.L.B. Coneglian, D.M. Freitas, and O.A. Oyarzabal, 2007. Litter Moisture and Footpad Dermatitis as Affected by Diets Formulated on an All-Vegetable Basis or Having the Inclusion of Poultry By-Product. J. Appl. Poult. Res. 16:344-350.

European Commission, 2009. REGULATION (EC) No 1069/2009 OF THE EUROPEAN PARLIAMENT AND OF THE COUNCIL of 21 October 2009 laying down health rules as regards animal by-products and derived products not intended for human consumption and repealing Regulation (EC) No 1774/2002 (Animal by-products Regulation). https://eur-lex.europa.eu/legalcontent/EN/TXT/PDF/?uri=CELEX:32009R1069\&rid=9

EFSA, 2007. Certain Aspects related to the Feeding of Animal Proteins to Farm Animals - Scientific Opinion of the Panel on Biological Hazards; Question N EFSA-Q-2007-084, Adopted on 17 October 2007; EFSA Journal (2007) 576, 1-41.

EFSA, 2011. Scientific Opinion on the revision of the quantitative risk assessment (QRA) of the BSE risk posed by processed animal proteins (PAPs). EFSA Journal 2011;9(1):1947.

GenStat 18 Committee, 2015. Genstat 18th Reference Manual: Release 1. Clarendon Press, Oxford, UK.

Hendriks, W.H., C.A. Butts, D.V. Thomas, K.A.C. James, P.C.A. Morel and M.W.A. Verstegen, 2002. Nutritional quality and variation of meat and bone meal. Asian Austral. J. Anim. 15(10): 15071516.

Hendriks, W.H., Y.H. Cottam, P.C.H. Morel, and D.V. Thomas, 2004. Source of the variation in meat and bone meal nutritional quality. Asian-Australasian Journal of Animal Sciences 17(1):94-101.

Kestin SC, Knowles TG, Tinch AE, Gregory NE (1992) The prevalence of leg weakness in broiler chickens assessed by gait scoring and its relationship to genotype. Vet Rec 131: 190-194

Kim, I. H., J. C. Schon, C. S. Kim, and J. D. Hancock, 1993. Use of meat and bone meal and fish meal as substitutes for soybean meal and tricalcium phosphate in diets for broiler chicks. Korean $\mathrm{J}$. Anim. Sci. 35: 421-426.

Leitgeb, R., H. Nesensohn, W. Zollitsch, and F. Baumann, 2001. Influence of different proportions of meat and bone meal in broiler feed on growing and carcass performance. Landbauforshung Volkenrode 223:104-109.

Leitgeb, R., P. Oberrauch, F. Baumann, and W. Wetscherek, 1998. Use of meat and bone meal in broiler diets. Die Bodenkultur 49:193-199.

Navidshad, B., M. Adibmoradi and J. Seifdavati, 2009. Effect of dietary levels of a modified meat meal on performance and small intestinal morphology of broiler chickens. African Journal of Biotechnology Vol. 8 (20), pp. 5620-5626.

Van Leeuwen P., J.M.V.M Mouwen, J.D. Van Der Klis, M.W.A. Verstegen, 2004. Morphology of the small intestinal mucosal surface of broilers in relation to age, diet formulation, small intestinal microflora and performance. Brit. Poult. Sci. 45: 41-48. 


\section{Appendix 1 Lay-out experimental room}

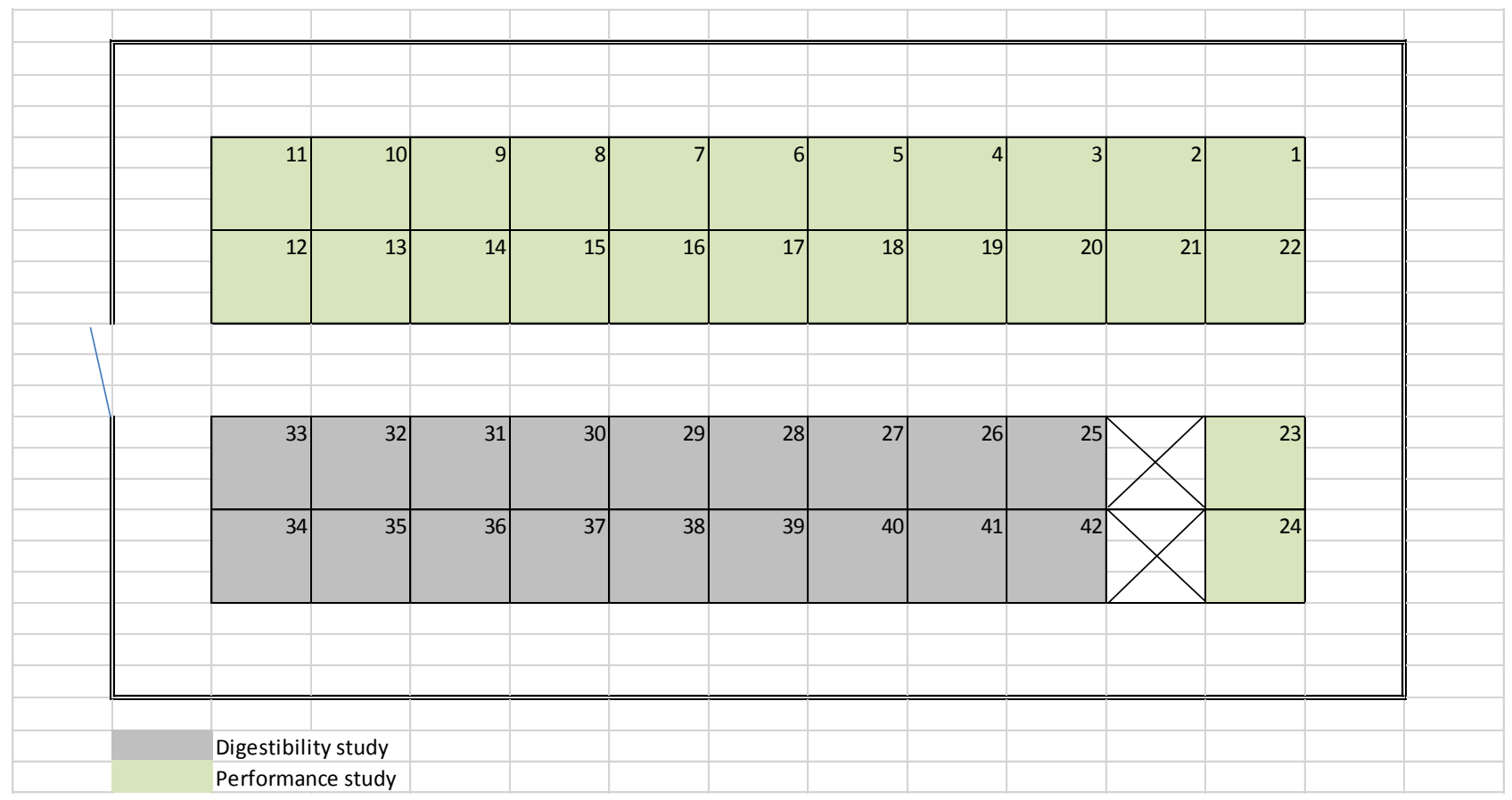




\section{Appendix 2 Realised temperature and humidity}

Table A3.1 Setting temperatures during experiment.

\begin{tabular}{cc} 
Age $(d)$ of the birds & Temperature setting $\left({ }^{\circ} \mathrm{C}\right)$ \\
0 & 34 \\
7 & 28 \\
14 & 25 \\
\hline 21 & 22 \\
\hline 28 & 20 \\
\hline 42 & 20
\end{tabular}

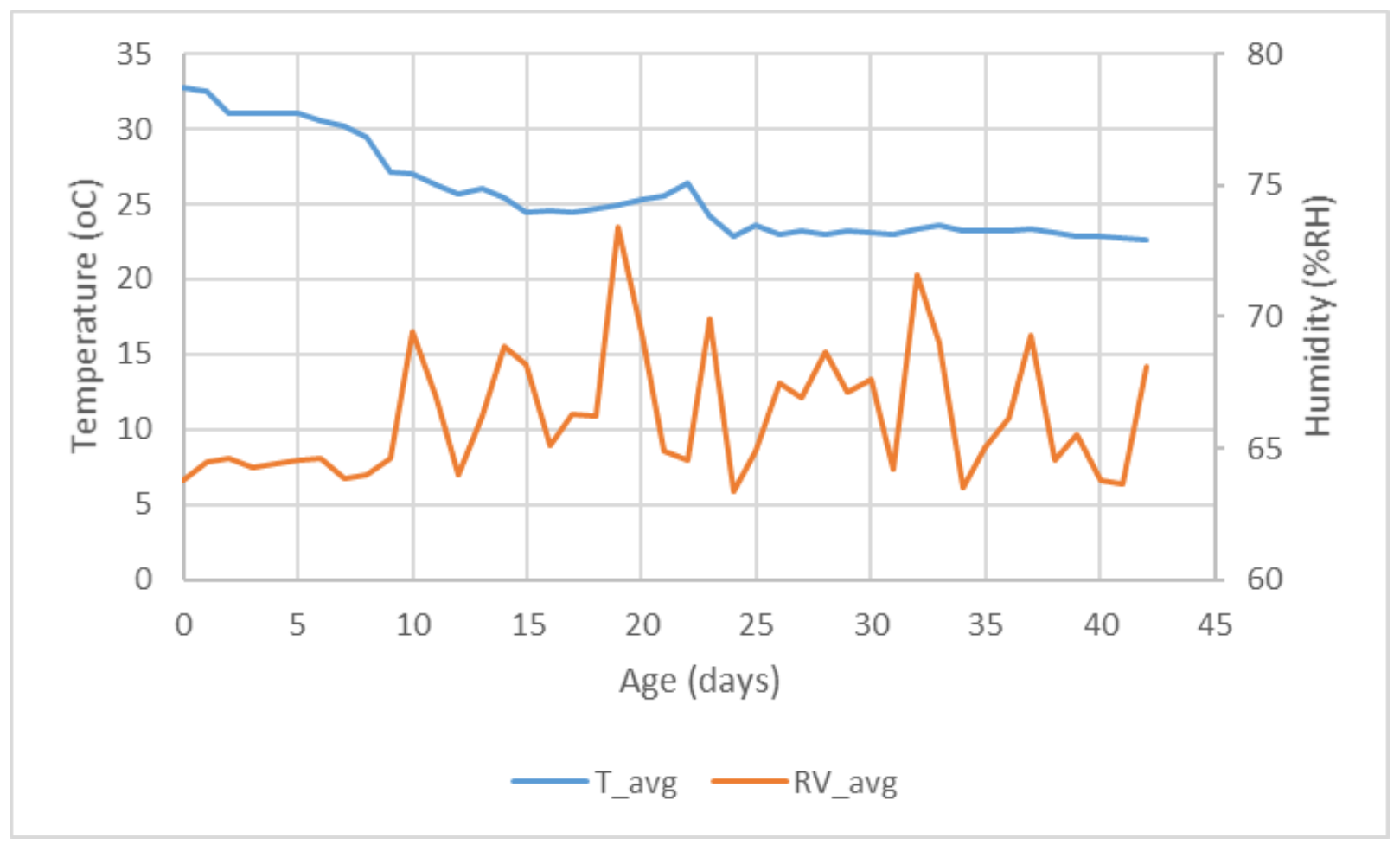

Figure A3.1 Realised temperature and humidity during experiment 


\section{Appendix 3 Calculated nutrient content of the PAPs}

\begin{tabular}{|c|c|c|c|}
\hline Nutrient & Unit & PAP1 & PAP2 \\
\hline Dry matter & g & 955.0 & 970.0 \\
\hline Crude Ash & $g$ & 98.0 & 210.0 \\
\hline Crude protein & $g$ & 621.0 & 620.0 \\
\hline RVETh & $\mathrm{g}$ & 147.0 & 110.0 \\
\hline $\mathrm{Ca}$ & $g$ & 18.2 & 84.0 \\
\hline$P$ & g & 14.7 & 46.0 \\
\hline K & $\mathrm{g}$ & 10.5 & 5.1 \\
\hline $\mathrm{Na}$ & $g$ & 6.5 & 5.0 \\
\hline $\mathrm{Cl}$ & $g$ & 6.1 & 3.3 \\
\hline $\mathrm{AME}_{\mathrm{n}}$ broiler & MJ & 13.42 & 12.12 \\
\hline LYS & $\mathrm{g}$ & 37.3 & 29.0 \\
\hline MET & $\mathrm{g}$ & 10.6 & 7.0 \\
\hline CYS & $g$ & 3.7 & 6.0 \\
\hline$M+C$ & $\mathrm{~g}$ & 14.3 & 13.0 \\
\hline TRP & $\mathrm{g}$ & 4.5 & 4.6 \\
\hline Dig. LYSpoultry & $g$ & 27.2 & 22.6 \\
\hline Dig. METpoultry & $\mathrm{g}$ & 6.6 & 5.5 \\
\hline Dig. CYSpoultry & $g$ & 4.0 & 4.1 \\
\hline Dig. M+Cpoultry & $\mathrm{g}$ & 10.7 & 9.6 \\
\hline Dig. THRpoultry & $g$ & 16.2 & 15.9 \\
\hline Dig. TRPpoultry & $\mathrm{g}$ & 3.5 & 3.7 \\
\hline Dig. ILEpoultry & $g$ & 16.1 & 14.4 \\
\hline Dig. ARGpoultry & $\mathrm{g}$ & 31.6 & 33.0 \\
\hline Dig.PHEpoultry & g & 17.7 & 16.6 \\
\hline Dig. HISpoultry & $g$ & 10.8 & 7.7 \\
\hline Dig. LEUpoultry & g & 32.9 & 30.4 \\
\hline Dig. TYRpoultry & $g$ & 11.2 & 14.4 \\
\hline Dig. VALpoultry & $g$ & 22.8 & 19.5 \\
\hline Dig. ALApoultry & $\mathrm{g}$ & 34.8 & 34.0 \\
\hline Dig. ASPpoultry & $\mathrm{g}$ & 34.2 & 33.8 \\
\hline Dig. GLUpoultry & $g$ & 58.5 & 62.4 \\
\hline Dig. GLYpoultry & $g$ & 49.5 & 56.9 \\
\hline Dig. PROpoultry & $g$ & 32.0 & 33.3 \\
\hline Dig. SERpoultry & $\mathrm{g}$ & 17.3 & 20.1 \\
\hline Retainable $\mathrm{P}$ & $\mathrm{g}$ & 9.1 & 28.5 \\
\hline Electrolyte balance & $\mathrm{kg}$ & 379.2 & 254.8 \\
\hline Ca : retainable $\mathrm{P}$ & & 2.0 & 3.0 \\
\hline
\end{tabular}




\section{Appendix 4 Experimental diets}

\begin{tabular}{|c|c|c|c|c|c|c|c|c|c|c|}
\hline & \multicolumn{4}{|c|}{ Starter $(0-10 d)$} & \multicolumn{3}{|c|}{ Grower $(10-28 d)$} & \multicolumn{3}{|c|}{ Finisher $(28-42$ d) } \\
\hline & & Control & PAP 1 & PAP 2 & Control & PAP 1 & PAP 2 & Control & PAP 1 & PAP 2 \\
\hline & & $\%$ & $\%$ & $\%$ & $\%$ & $\%$ & $\%$ & $\%$ & $\%$ & $\%$ \\
\hline Corn & & 47.00 & 47.00 & 47.00 & 45.00 & 45.00 & 45.00 & 45.00 & 45.00 & 45.00 \\
\hline Wheat & & 13.15 & 13.15 & 13.15 & 16.43 & 13.00 & 14.99 & 18.20 & 14.33 & 16.18 \\
\hline Potato protein & & 3.32 & 3.32 & 3.32 & 3.20 & 3.18 & 3.20 & 3.20 & 0.03 & 2.91 \\
\hline Soybean meal & & 28.84 & 17.53 & 17.41 & 26.12 & 17.66 & 19.14 & 25.37 & 20.92 & 19.88 \\
\hline PAP1 (porcine meal 1) & & -- & 9.00 & -- & -- & 8.50 & -- & -- & 9.00 & -- \\
\hline PAP2 (porcine meal 7) & & -- & -- & 9.00 & -- & -- & 7.00 & -- & -- & 6.00 \\
\hline Oat hulls & & -- & -- & -- & 0.61 & 1.97 & 1.61 & 0.55 & 1.52 & 1.42 \\
\hline Diamol (filler) & & -- & 3.32 & 5.17 & -- & 2.40 & 2.50 & -- & 1.91 & 2.47 \\
\hline Palm oil & & 2.00 & 2.00 & 2.00 & 2.00 & 2.00 & 2.00 & 2.00 & 2.00 & 2.00 \\
\hline Soy oil & & 1.14 & 0.65 & 0.98 & 2.70 & 2.79 & 2.55 & 2.67 & 2.79 & 2.78 \\
\hline Lime stone & & 1.50 & 1.26 & 0.07 & 1.27 & 1.03 & 0.15 & 1.04 & 0.79 & 0.08 \\
\hline Monocalcium phosphate & & 1.72 & 1.43 & 0.46 & 1.36 & 1.08 & 0.36 & 0.86 & 0.51 & -- \\
\hline Salt & & 0.15 & 0.04 & 0.06 & 0.12 & 0.04 & 0.08 & 0.14 & 0.04 & 0.10 \\
\hline Sodium bicarbonate & & 0.28 & 0.23 & 0.24 & 0.28 & 0.20 & 0.22 & 0.26 & 0.18 & 0.21 \\
\hline Potassium carbonate & & -- & -- & -- & -- & 0.18 & 0.21 & -- & 0.02 & 0.17 \\
\hline Premix & & 0.50 & 0.50 & 0.50 & 0.50 & 0.50 & 0.50 & 0.50 & 0.50 & 0.50 \\
\hline Clinacox (anti-coccidial) & & 0.02 & 0.02 & 0.02 & 0.02 & 0.02 & 0.02 & -- & -- & -- \\
\hline Rovabio Excel AP & & 0.01 & 0.01 & 0.01 & 0.01 & 0.01 & 0.01 & 0.01 & 0.01 & 0.01 \\
\hline L-Lysine HCL & & 0.12 & 0.20 & 0.25 & 0.13 & 0.13 & 0.17 & 0.03 & 0.10 & 0.07 \\
\hline DL-Methionine & & 0.24 & 0.28 & 0.29 & 0.23 & 0.25 & 0.25 & 0.17 & 0.22 & 0.19 \\
\hline Phytase & & 0.01 & 0.05 & 0.06 & 0.01 & 0.02 & 0.01 & -- & 0.07 & 0.01 \\
\hline L-Threonine & & -- & 0.01 & 0.01 & -- & 0.02 & 0.01 & -- & 0.03 & 0.01 \\
\hline L-Arginine & & -- & -- & -- & -- & 0.02 & -- & -- & -- & -- \\
\hline L-Valine & & -- & -- & -- & 0.01 & -- & 0.02 & -- & 0.03 & 0.01 \\
\hline Total & & 100.00 & 100.00 & 100.00 & 100.00 & 100.00 & 100.00 & 100.00 & 100.00 & 100.00 \\
\hline Dry Matter & $\mathrm{g}$ & 882 & 892 & 894 & 883 & 893 & 891 & 882 & 891 & 889 \\
\hline Crude ash & $\mathrm{g}$ & 63 & 92 & 99 & 56 & 78 & 72 & 49 & 66 & 65 \\
\hline Crude protein & $\mathrm{g}$ & 223 & 225 & 225 & 211 & 220 & 220 & 208 & 215 & 215 \\
\hline Crude Fat & $\mathrm{g}$ & 64 & 69 & 69 & 78 & 89 & 82 & 78 & 90 & 84 \\
\hline Crude fibre & $\mathrm{g}$ & 24 & 20 & 20 & 25 & 25 & 25 & 25 & 25 & 25 \\
\hline Starch & $\mathrm{g}$ & 363 & 362 & 362 & 369 & 350 & 361 & 379 & 357 & 367 \\
\hline Sugar & $\mathrm{g}$ & 39 & 28 & 28 & 37 & 28 & 30 & 37 & 31 & 31 \\
\hline NSP & $\mathrm{g}$ & 138 & 123 & 118 & 139 & 134 & 132 & 139 & 138 & 133 \\
\hline MEbroiler & MJ & 12.10 & 12.10 & 12.10 & 12.50 & 12.50 & 12.50 & 12.60 & 12.60 & 12.60 \\
\hline $\mathrm{Ca}$ & $\mathrm{g}$ & 9.2 & 9.2 & 9.2 & 7.7 & 7.7 & 7.7 & 6.1 & 6.1 & 6.1 \\
\hline $\mathrm{P}$ & $\mathrm{g}$ & 7.3 & 7.3 & 7.9 & 6.4 & 6.4 & 6.9 & 5.3 & 5.3 & 5.7 \\
\hline $\mathrm{OP}$ & $\mathrm{g}$ & 4.4 & 4.4 & 4.4 & 3.7 & 3.7 & 3.7 & 2.8 & 2.8 & 2.8 \\
\hline $\mathrm{Ca}: \mathrm{oP}$ & & 2.1 & 2.1 & 2.1 & 2.1 & 2.1 & 2.1 & 2.2 & 2.2 & 2.2 \\
\hline IP & $\mathrm{g}$ & 2.3 & 1.8 & 1.8 & 2.2 & 1.8 & 1.9 & 2.2 & 1.9 & 1.9 \\
\hline $\mathrm{Mg}$ & $\mathrm{g}$ & 1.4 & 1.3 & 1.2 & 1.4 & 1.3 & 1.3 & 1.4 & 1.4 & 1.3 \\
\hline $\mathrm{Na}$ & $\mathrm{g}$ & 1.4 & 1.4 & 1.4 & 1.3 & 1.3 & 1.3 & 1.3 & 1.3 & 1.3 \\
\hline K & $\mathrm{g}$ & 8.5 & 7.0 & 6.4 & 8.0 & 8.0 & 8.0 & 7.9 & 7.9 & 7.9 \\
\hline $\mathrm{Cl}$ & $\mathrm{g}$ & 1.8 & 1.8 & 1.8 & 1.6 & 1.6 & 1.6 & 1.5 & 1.5 & 1.5 \\
\hline EB & meq & 228 & 189 & 176 & 215 & 215 & 215 & 215 & 215 & 215 \\
\hline dLYS & $\mathrm{g}$ & 11.5 & 11.5 & 11.5 & 10.8 & 10.8 & 10.8 & 9.9 & 9.9 & 9.9 \\
\hline dMET & $\mathrm{g}$ & 5.6 & 5.9 & 5.9 & 5.3 & 5.5 & 5.4 & 4.7 & 4.9 & 4.8 \\
\hline dCYS & $\mathrm{g}$ & 3.0 & 2.6 & 2.6 & 2.8 & 2.6 & 2.7 & 2.8 & 2.6 & 2.7 \\
\hline $\mathrm{dM}+\mathrm{C}$ & $\mathrm{g}$ & 8.5 & 8.5 & 8.5 & 8.1 & 8.1 & 8.1 & 7.5 & 7.5 & 7.5 \\
\hline dTHR & $\mathrm{g}$ & 7.5 & 7.5 & 7.5 & 7.0 & 7.0 & 7.0 & 6.8 & 6.8 & 6.8 \\
\hline dTRP & $\mathrm{g}$ & 2.3 & 2.1 & 2.1 & 2.2 & 2.2 & 2.2 & 2.2 & 2.2 & 2.2 \\
\hline dILE & $\mathrm{g}$ & 8.5 & 7.8 & 7.6 & 8.0 & 7.6 & 7.6 & 7.9 & 7.1 & 7.5 \\
\hline dARG & $\mathrm{g}$ & 12.9 & 12.0 & 12.1 & 12.0 & 12.0 & 12.0 & 11.8 & 11.8 & 11.8 \\
\hline dPHE & $\mathrm{g}$ & 9.4 & 8.5 & 8.3 & 8.8 & 8.3 & 8.4 & 8.8 & 8.5 & 8.4 \\
\hline dHIS & $\mathrm{g}$ & 5.0 & 4.6 & 4.3 & 4.7 & 4.5 & 4.4 & 4.6 & 4.6 & 4.4 \\
\hline dLEU & $\mathrm{g}$ & 15.6 & 14.8 & 14.5 & 14.7 & 14.5 & 14.4 & 14.5 & 14.8 & 14.3 \\
\hline dTYR & $\mathrm{g}$ & 6.6 & 5.8 & 6.1 & 6.2 & 5.7 & 6.1 & 6.1 & 5.9 & 6.0 \\
\hline dVAL & $\mathrm{g}$ & 9.2 & 9.0 & 8.6 & 8.8 & 8.8 & 8.8 & 8.6 & 8.6 & 8.6 \\
\hline
\end{tabular}




\section{Appendix 5 Processing methods PAPs (EC, 2009)}

PAP 1 - Processing method 1 (pressure sterilisation) Reduction

1. If the particle size of the animal by-products to be processed is more than 50 millimetres, the animal by-products must be reduced in size using appropriate equipment, set so that the particle size after reduction is no greater than 50 millimetres. The effectiveness of the equipment must be checked daily and its condition recorded. If checks disclose the existence of particles larger than 50 millimetres, the process must be stopped and repairs made before the process is resumed. Time, temperature and pressure

2. The animal by-products with the particle size of no greater than 50 millimetres must be heated to a core temperature of more than $133^{\circ} \mathrm{C}$ for at least 20 minutes without interruption at a pressure (absolute) of at least 3 bars. The pressure must be produced by the evacuation of all air in the sterilisation chamber and the replacement of the air by steam ('saturated steam'); the heat treatment may be applied as the sole process or as a pre- or post-process sterilisation phase.

3. The processing may be carried out in batch or continuous systems.

PAP 2 - Processing method 7

1. Any processing method authorised by the competent authority where the following have been demonstrated by the operator to that authority:

(a) the identification of relevant hazards in the starting material, in view of the origin of the material, and of the potential risks in view of the animal health status of the Member State or the area or zone where the method is to be used;

(b) the capacity of the processing method to reduce those hazards to a level which does not pose any significant risks to public and animal health;

(c) the sampling of the final product on a daily basis over a period of 30 production days in compliance with the following microbiological standards:

(i) Samples of material taken directly after the treatment:

Clostridium perfringens absent in $1 \mathrm{~g}$ of the products

(ii) Samples of material taken during or upon withdrawal from storage:

Salmonella: absence in 25g: $n=5, c=0, m=0, M=0$

Enterobacteriaceae: $n=5, c=2 ; m=10 ; M=300$ in $1 \mathrm{~g}$

where:

$\mathrm{n}=$ number of samples to be tested;

$\mathrm{m}=$ threshold value for the number of bacteria; the result is considered

satisfactory if the number of bacteria in all samples does not exceed $\mathrm{m}$;

$M=$ maximum value for the number of bacteria; the result is considered unsatisfactory if the number of bacteria in one or more samples is $\mathrm{M}$ or more; and

$\mathrm{c}=$ number of samples the bacterial count of which may be between $\mathrm{m}$ and $\mathrm{M}$, the samples still being considered acceptable if the bacterial count of the other samples is $\mathrm{m}$ or less.

2. Details of the critical control points under which each processing plant satisfactorily complies with the microbiological standards must be recorded and maintained so that the operator and the competent authority can monitor the operation of the processing plant. The information to be recorded and monitored must include the particle size, and, as appropriate, the critical temperature, the absolute time, pressure profile, raw material feed rate and fat recycling rate.

3. By way of derogation from point 1 , the competent authority may authorise the use of processing methods which have been approved prior to the date of entry into application of this Regulation, in accordance with Chapter III of Annex V to Regulation (EC) No 1774/2002. L 54/32 Official Journal of the European Union 26.2.2011 EN

4. The competent authority shall permanently or temporarily suspend the application of processing methods referred to in points 1 and 3, if it obtains evidence that any of the circumstances specified in point 1 (a) or (b) have substantially changed.

5. The competent authority shall inform the competent authority of another Member State upon request about the information at its disposal under points 1 and 2 in relation to an authorised processing method. 


\section{Appendix 6 Scores for friability and wetness of the litter}

\begin{tabular}{cl}
\multicolumn{1}{l}{ Friability } & \\
\hline $\mathbf{1}$ & Description \\
\hline $\mathbf{2}$ & Complete caked litter \\
\hline $\mathbf{3}$ & $80-90 \%$ of the area is caked \\
\hline $\mathbf{4}$ & $70-80 \%$ of the area is caked \\
\hline $\mathbf{5}$ & $60-70 \%$ of the area is caked \\
\hline $\mathbf{6}$ & $50-60 \%$ of the area is caked \\
\hline $\mathbf{7}$ & $30 \%$ of the area is caked \\
\hline $\mathbf{8}$ & $10 \%$ of the area is caked \\
\hline $\mathbf{9}$ & Friable litter, some litter particles are caked \\
\hline $\mathbf{1 0}$ & Friable litter, no caked litter particles \\
\hline
\end{tabular}

\begin{tabular}{cl}
\multicolumn{1}{c}{ Wetness } & \\
\hline \multicolumn{1}{c}{ Score } & Wescription \\
\hline $\mathbf{2}$ & $\begin{array}{l}\text { Wet litter, total area by pressure on the litter water is appearing } \\
\text { appearing }\end{array}$ \\
\hline $\mathbf{3}$ & $\begin{array}{l}\text { Wet litter, beneath drinking line by pressure on the litter no water is } \\
\text { appearing }\end{array}$ \\
\hline $\mathbf{4}$ & Wet litter, dark coloured. Litter can be pressed ball-shaped. \\
\hline $\mathbf{5}$ & Wet litter, dark coloured. Ridges beneath drinking line \\
\hline $\mathbf{6}$ & $\begin{array}{l}\text { Almost dry litter, small ridges beneath drinking line. Litter between } \\
\text { drinking line and feeders is still friable }\end{array}$ \\
\hline $\mathbf{7}$ & $\begin{array}{l}\text { Almost dry litter, dark coloured beneath drinking line and in other } \\
\text { areas light coloured, ridge formation beneath drinking lines just } \\
\text { started }\end{array}$ \\
\hline $\mathbf{8}$ & Almost dry litter, light coloured, no ridges beneath drinking line \\
\hline $\mathbf{9}$ & Dry litter, light coloured \\
\hline
\end{tabular}




\section{Appendix 7 Score card footpad lesions broiler chickens}
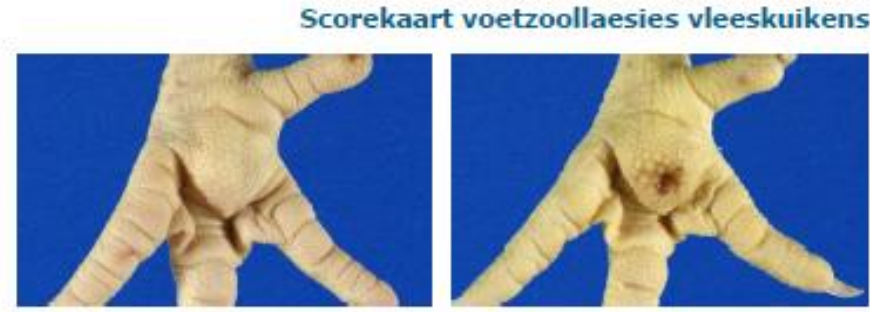

Klasse 0 - glad, geen laesie
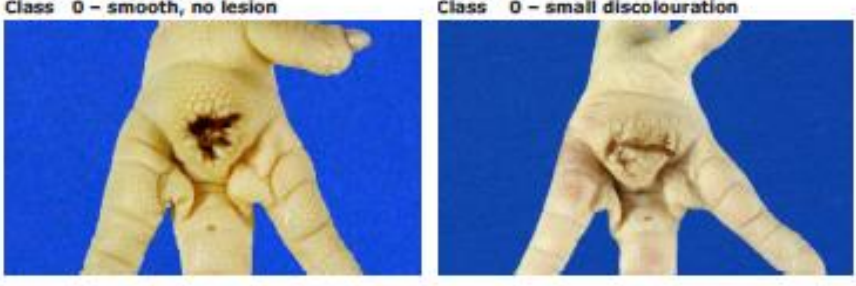

Klasse 1 - oppervlakkige laesie, verkleuring

Klasse 1-donkere papillen, geen ontsteking
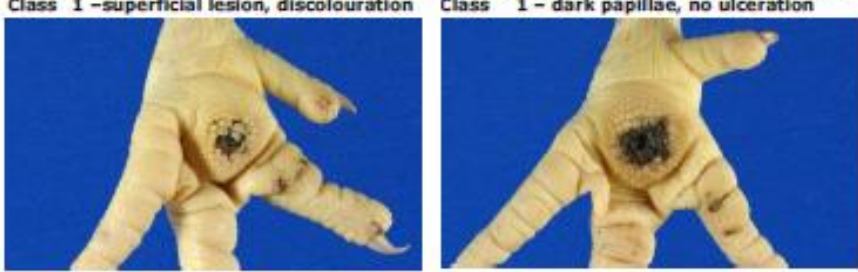

Klasse 2 - donkere papillen en zweer

Klasse 2 - zweer bedekt met korst Class 2 - dark papillae and uicer

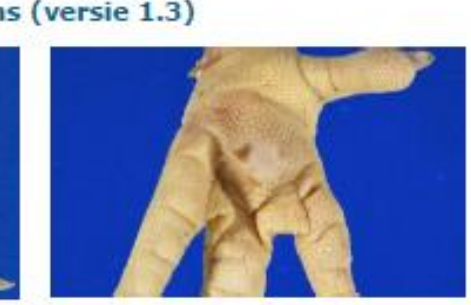

Klasse 0 - (bijna) genezen (litteken)

Klasse 0 - (bijna) genezen (litteken)

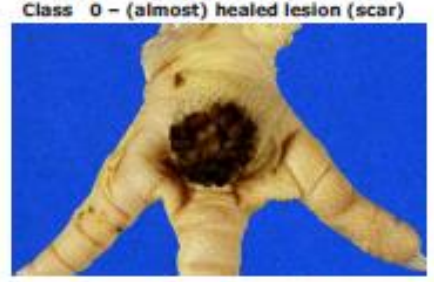

Klasse 1 - aanzientijke verkleuring

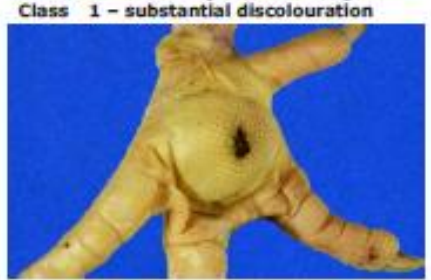

Klasse 2 - abces/'bumble foot', gerwollen Class 2 - abscess/bumble foot, swollen

uitleg scorekaart voetzoollaesies vleeskuikens (Methodiek @Berg) - a photo guide to broiler foot health classification (version 1.3)

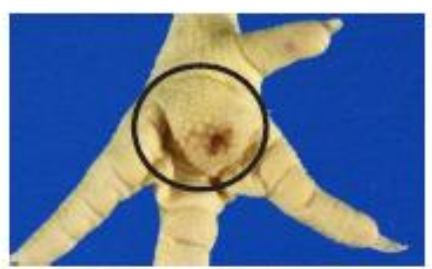

Klasse 0 - geen laesic Class 0 - no lesion

Klasse 0-Geen laesies: geen laesie of zeer kleine en oppervakkige aantasting (geringe verkleuring op een klein oppervlak), milde Myperkeratose, (oude) littekens. Opperviakte verkleuring heeft maximaal de groctte van

een ludferkopje.
Alleen de voetzool (omcirkelde deed) wordt meegenomen in de becordeling

class 0 - No lesion: no lesions or very small and superficial lesions, slight discolouration on a limited area, mild hyperkeratosis, old scars. Maximum ares discolouration: size of a match head.

Only the foot path (dircled area) should be evaluated.

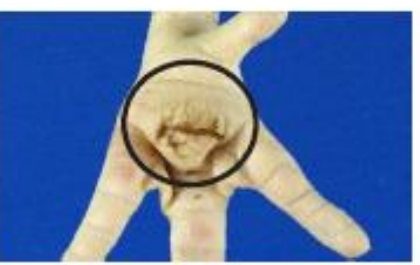

Klasse 1 - milde laesie Class 1 - mild lesion

klasse 1 - Milde laesie: verkleuring van de voetzool (groter dan een luciferkopje), oppervlakdige aantasting, vergrote en/of verkieurde papillen,

Alleen aantasting van de opperhuid.

Alleen de voetzoal (amcirkelde ded) wordt meegenomen in de beoordeling.

Class 1 - Mild lesion: discolouration of the foot pad (larger than the size of a match head), superficial damage, dark and/or large papillae.

Only the foot path (circled ares) should be evaluated.

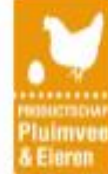

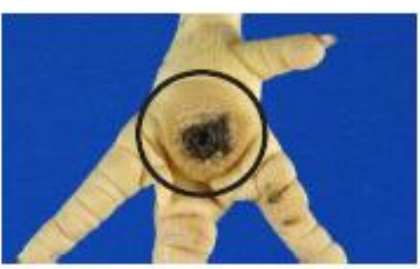

Klasse 2 - ernstige laesie Class 2 - severe lesion

Klasse 2 - Ernstige laesie: zweer met bloedkorsten van enige omvang, (tekenen van) bloeduitstortingen of emstig gezwollen voetzolen (abces).

Aantasting tot in de diepere huidlagen.

Alieen de voetzool (omainkelde deed) wordt meegenomen in de beoordeling.

Class 2 - Severe lesion: Ulcers with scabs of significant size, signs of haemorrthages or severely swollen foot pad (abscess).

Only the foot path (ardied ares) should be evaluated. 


\section{Appendix 8 Performance results per feeding phase}

Table A8.1 Growth performance results starter period (0 - 10 days).

\begin{tabular}{lrrrrr} 
& Control & PAP 1 & PAP 2 & F-prob & LSD \\
\hline Body weight D0 $(\mathrm{g})$ & 40 & 40 & 40 & 0.903 & 0.6 \\
\hline Body weight D10 $(\mathrm{g})$ & $300^{\mathrm{b}}$ & $318^{\mathrm{a}}$ & $306^{\mathrm{ab}}$ & 0.030 & 13.2 \\
\hline Body weight gain $(\mathrm{g})$ & $260^{\mathrm{b}}$ & $278^{\mathrm{a}}$ & $266^{\mathrm{ab}}$ & 0.034 & 13.5 \\
\hline Body weight gain $(\mathrm{g} / \mathrm{d})$ & $26.0^{\mathrm{b}}$ & $27.8^{\mathrm{a}}$ & $26.6^{\mathrm{ab}}$ & 0.034 & 1.35 \\
\hline Mortality $(\%)$ & 1.3 & 0.0 & 0.0 & 0.385 & 2.12 \\
\hline Feed conversion ratio $(\mathrm{g} / \mathrm{g})$ & $1.005^{\mathrm{b}}$ & $1.051^{\mathrm{a}}$ & $1.060^{\mathrm{a}}$ & $<.001$ & 0.0177 \\
\hline Feed intake $(\mathrm{g})$ & $261^{\mathrm{b}}$ & $292^{\mathrm{a}}$ & $282^{\mathrm{a}}$ & $<.001$ & 12.8 \\
\hline Feed intake $(\mathrm{g} / \mathrm{d})$ & $26.1^{\mathrm{b}}$ & $29.2^{\mathrm{a}}$ & $28.2^{\mathrm{a}}$ & $<.001$ & 1.28 \\
\hline Water/feed ratio & 2.70 & 2.55 & 2.58 & 0.280 & 0.202 \\
\hline Water intake $(\mathrm{ml})$ & 700 & 744 & 726 & 0.383 & 64.6 \\
\hline Water intake $(\mathrm{ml} / \mathrm{d})$ & 70.0 & 74.4 & 72.6 & 0.383 & 6.46 \\
\hline
\end{tabular}

a,b different subscripts in a row mean significant differences $(P<0.05)$

Table A8.2 Growth performance results grower period (10 - 28 days).

\begin{tabular}{|c|c|c|c|c|c|}
\hline & Control & PAP 1 & PAP 2 & F-prob & LSD \\
\hline Body weight D10 (g) & $303^{b}$ & $318^{a}$ & $306^{a b}$ & 0.025 & 11.0 \\
\hline Body weight D28 (g) & 1934 & 1966 & 1932 & 0.392 & 56.6 \\
\hline Body weight gain (g) & 1631 & 1648 & 1626 & 0.645 & 50.9 \\
\hline Body weight gain $(\mathrm{g} / \mathrm{d})$ & 90.6 & 91.6 & 90.3 & 0.645 & 2.83 \\
\hline Mortality (\%) & 3.0 & 1.8 & 0.0 & 0.400 & 4.56 \\
\hline Feed conversion ratio $(\mathrm{g} / \mathrm{g})$ & $1.272^{b}$ & $1.311^{\mathrm{a}}$ & $1.290^{a b}$ & 0.006 & 0.0223 \\
\hline Feed intake (g) & $2075^{b}$ & $2160^{a}$ & $2097^{b}$ & 0.015 & 57.6 \\
\hline Feed intake $(\mathrm{g} / \mathrm{d})$ & $115.3^{b}$ & $120.0^{a}$ & $116.5^{b}$ & 0.015 & 3.20 \\
\hline Water/feed ratio & 1.81 & 1.77 & 1.80 & 0.348 & 0.062 \\
\hline Water intake $(\mathrm{ml})$ & 3749 & 3815 & 3771 & 0.612 & 139.3 \\
\hline Water intake $(\mathrm{ml} / \mathrm{d})$ & 208.3 & 212.0 & 209.5 & 0.612 & 7.74 \\
\hline
\end{tabular}

$a, b$ different subscripts in a row mean significant differences $(P<0.05)$ 
Table A8.3 Growth performance results starter and grower period ( 0 - 28 days).

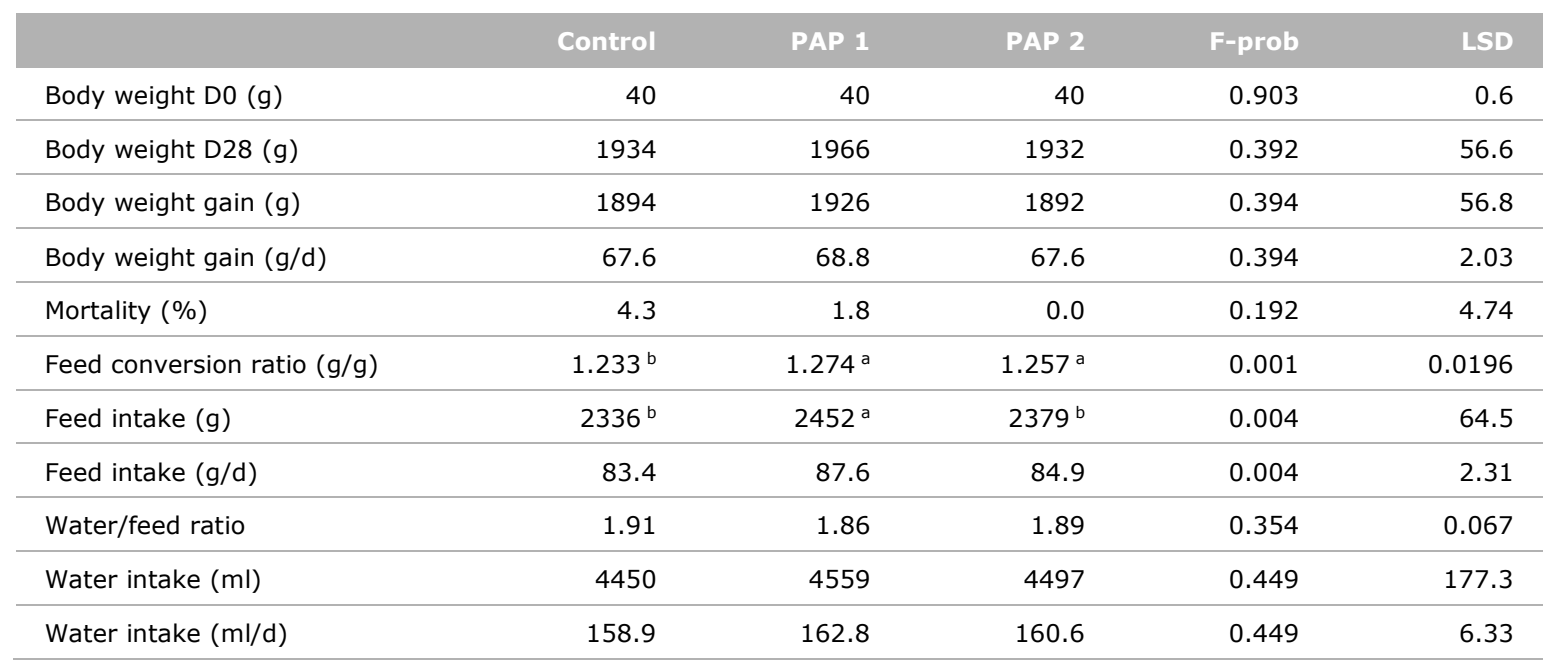

$a, b$ different subscripts in a row mean significant differences $(P<0.05)$

Table A8.4 Growth performance results finisher period (28 - 42 days).

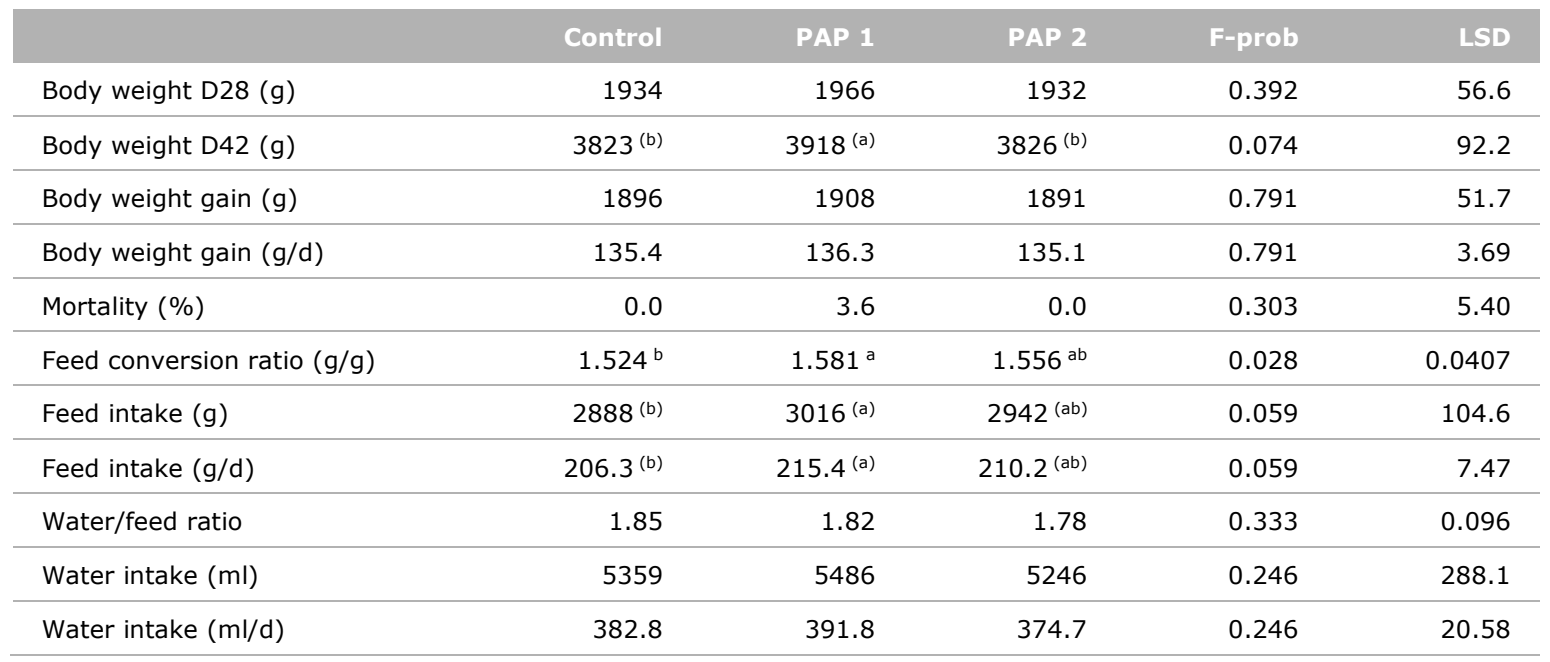

$a, b$ different subscripts in a row mean significant differences $(P<0.05)$

$a, b$ different subscripts in a row in parenthesis indicate near significant differences (tendency) $(0.05 \leq P<0.10)$

Table A8.5 Growth performance results grower and finisher period (10 - 42 days).

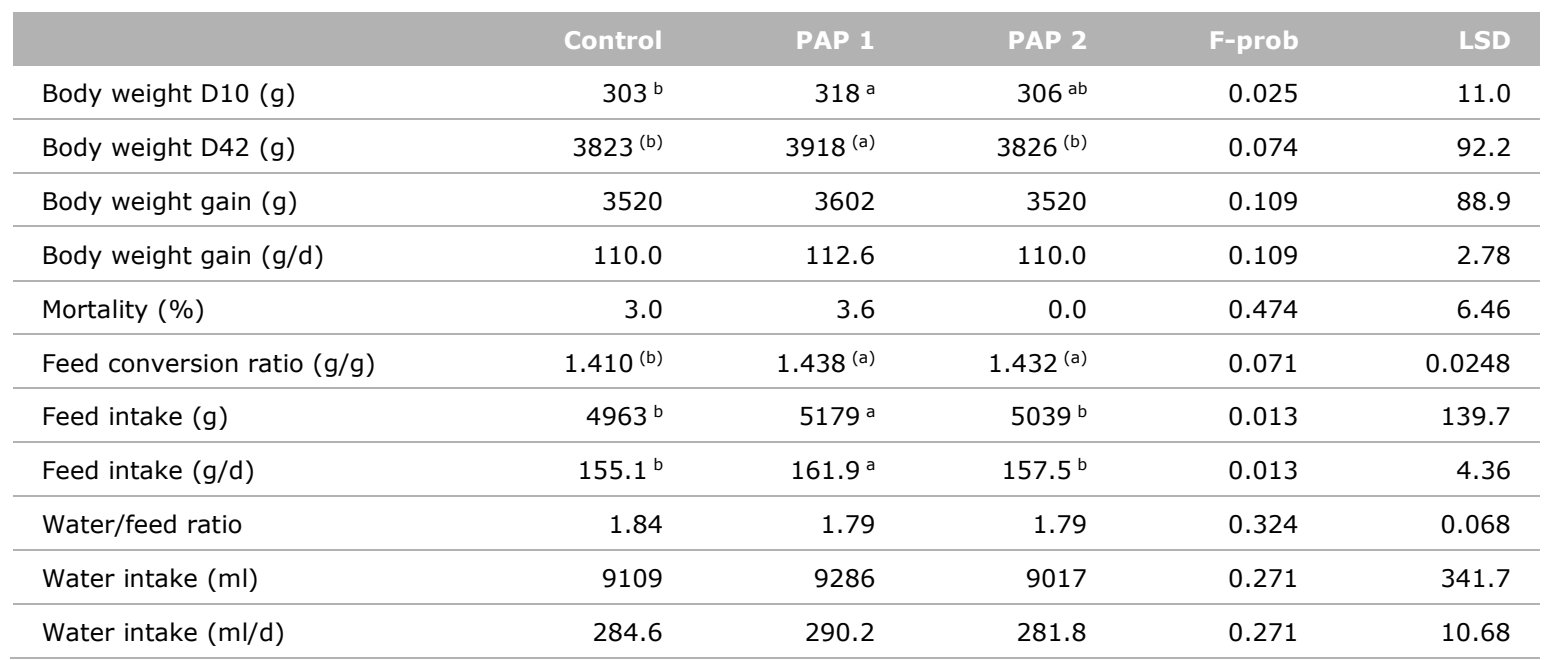

$a, b$ different subscripts in a row mean significant differences $(P<0.05)$

$a, b$ different subscripts in a row in parenthesis indicate near significant differences (tendency) $(0.05 \leq P<0.10)$ 


\section{Appendix 9 Animal welfare}

Table A9.1 Effect of dietary treatment on the visual friability of the litter at 27 and 41 days of age.

\begin{tabular}{lrrrr} 
Age (days) & Control & PAP 1 & PAP 2 & Avg. Age \\
10 & 9.0 & 9.0 & 9.0 & 9.0 \\
\hline 27 & 8.0 & 7.6 & 7.5 & 7.7 \\
\hline 41 & 6.6 & 6.0 & 6.0 & 6.2 \\
\hline Average per treatment & $\mathbf{7 . 9}$ & $\mathbf{7 . 5}$ & $\mathbf{7 . 5}$ & \\
\hline & & & Age & Treatment*Age \\
\hline & & Treatment & $<.001$ & 0.652 \\
\hline & F-Prob. & 0.117 & 0.4 & 0.6 \\
\hline
\end{tabular}

Table A9.2 Effect of dietary treatment on the visual wetness of the litter at 27 and 41 days of age.

\begin{tabular}{|c|c|c|c|c|}
\hline & Control & PAP 1 & PAP 2 & Avg. Age \\
\hline 10 & 9.0 & 9.0 & 9.0 & 9.0 \\
\hline 27 & 8.0 & 7.8 & 7.5 & 7.8 \\
\hline 41 & 6.8 & 6.6 & 6.6 & 6.7 \\
\hline \multirow[t]{4}{*}{ Average per treatment } & 7.9 & 7.8 & 7.7 & \\
\hline & & Treatment & Age & Treatment*Age \\
\hline & F-Prob. & 0.215 & $<.001$ & 0.622 \\
\hline & LSD & 0.3 & 0.3 & 0.5 \\
\hline
\end{tabular}

Table A9.3 Effect of dietary treatment on the footpad score of broilers at 27 and 41 days of age.

\begin{tabular}{lrrrrr} 
& & Control & PAP 1 & Avg. Age \\
27 & 1.8 & 0.0 & 0.0 & $0.6^{\text {b }}$ \\
\hline 41 & & 3.1 & 1.6 & 3.1 & $2.6^{\text {a }}$ \\
\hline Average per treatment & $\mathbf{2 . 5}$ & $\mathbf{1 . 6}$ & $\mathbf{0 . 8}$ & \\
\hline & & & & Age & Treatment*Age \\
\hline & & & Treatment & 0.160 & 0.853 \\
\hline & F-Prob. & 0.626 & 2.83 & 4.91 \\
\hline
\end{tabular}

Table A9.4 Effect of dietary treatment on the gait score of broilers at 27 and 38 days of age.

\begin{tabular}{lrrrrr} 
& & PAP 1 & PAP 2 & Avg. Age \\
27 & 2.5 & 2.3 & 2.5 & $2.4^{\text {b }}$ \\
\hline 38 & & 2.9 & 3.0 & 2.9 & $2.9^{\text {a }}$ \\
\hline Average per treatment & $\mathbf{2 . 7}$ & $\mathbf{2 . 7}$ & $\mathbf{2 . 7}$ & \\
\hline & & & & Age & Treatment*Age \\
\hline & & Treatment & $<.001$ & 0.239 \\
\hline & F-Prob. & 0.849 & 0.14 & 0.24 \\
\hline
\end{tabular}




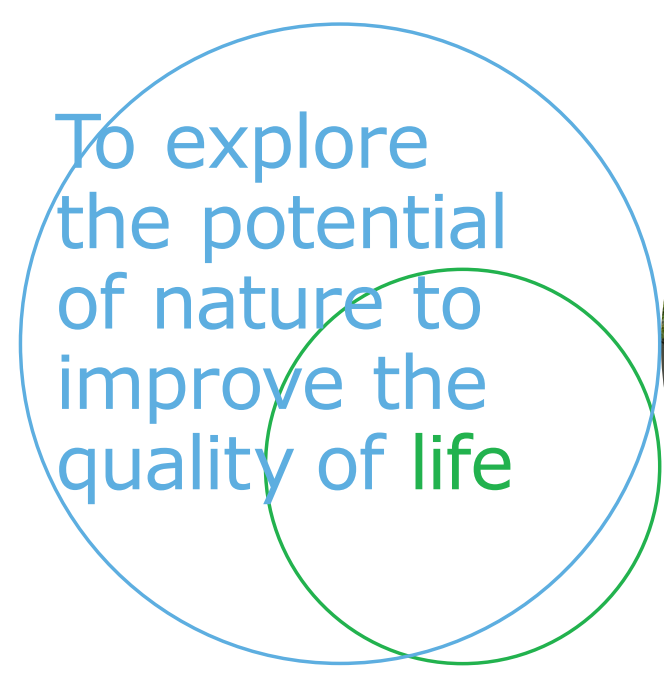

Wageningen Livestock Research P.O. Box 338

6700 AH Wageningen

The Netherlands

$\mathrm{T}+31(0) 317483953$

E info.livestockresearch@wur.nl www.wur.nl/livestock-research

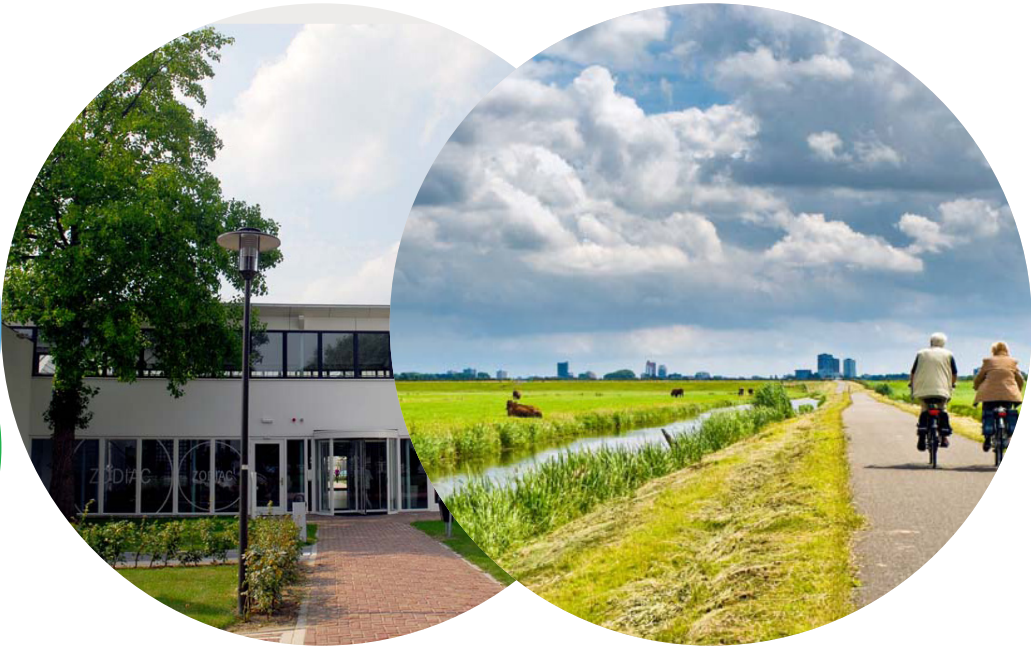

Wageningen Livestock Research creates science based solutions for a sustainable and profitable livestock sector. Together with our clients, we integrate scientific knowledge and practical experience to develop livestock concepts for future generations.

Wageningen Livestock Research is part of Wageningen University \& Research. Together we work on the mission: 'To explore the potential of nature to improve the quality of life'. A staff of 6,500 and 10,000 students from over 100 countries are working worldwide in the domain of healthy food and living environment for governments and the business community-at-large. The strength of Wageningen University \& Research lies in its ability to join the forces of specialised research institutes and the university. It also lies in the combined efforts of the various fields of natural and social sciences. This union of expertise leads to scientific breakthroughs that can quickly be put into practice and be incorporated into education. This is the Wageningen Approach. 